\title{
Country Schoolgirls: A Study of Rural Women and the Rise of Public Education, 1820-1914
}

\author{
Allyson Perry \\ West Virginia University
}

Follow this and additional works at: https://researchrepository.wvu.edu/etd

\section{Recommended Citation}

Perry, Allyson, "Country Schoolgirls: A Study of Rural Women and the Rise of Public Education, 1820-1914" (2014). Graduate Theses, Dissertations, and Problem Reports. 452.

https://researchrepository.wvu.edu/etd/452

This Thesis is protected by copyright and/or related rights. It has been brought to you by the The Research Repository @ WVU with permission from the rights-holder(s). You are free to use this Thesis in any way that is permitted by the copyright and related rights legislation that applies to your use. For other uses you must obtain permission from the rights-holder(s) directly, unless additional rights are indicated by a Creative Commons license in the record and/ or on the work itself. This Thesis has been accepted for inclusion in WVU Graduate Theses, Dissertations, and Problem Reports collection by an authorized administrator of The Research Repository @ WVU. For more information, please contact researchrepository@mail.wvu.edu. 
Country Schoolgirls:

A Study of Rural Women and the Rise of Public Education, 1820-1914

\author{
Allyson Perry \\ Thesis submitted to the \\ Eberly College of Arts and Sciences \\ at West Virginia University \\ in partial fulfillment of the requirements \\ for the degree of
}

\author{
Master of Arts \\ in \\ History
}
Kenneth Fones-Wolf, Ph.D., Chair Elizabeth Fones-Wolf, Ph.D. Kimberly Welch, Ph.D.
Department of History
Morgantown, West Virginia 2014

Keywords: History of Education; West Virginia; Pennsylvania; Rural Women; Appalachian History

Copyright 2014 Allyson Perry 


\title{
ABSTRACT \\ Country Schoolgirls: A Study of Rural Women and the Rise of Public Education, 1820-1914
}

\begin{abstract}
Allyson Perry
This thesis explores the rise of public education, its influence on rural society, and the ways that farmwomen used schooling for a variety of purposes. Throughout the nineteenth century, more opportunities for women appeared as communities in the mountainous areas of West Virginia and Pennsylvania established free, public schools. With these social developments came an attempt to balance the public's perception of women's role in rural society. Administrators charged with implementing state-wide, public education had to set boundaries on women's advancement as they reacted to the public's changing ideas of women's proper role. Confronting these ideas set forth by administrators, the girls who attended public schools received an education that provided additional tools and new experiences, which were individually transformative. By the turn of the century, farmwomen saw themselves as an extension of the country school, which they believed was the nexus of their community. They advocated for their own and their family's education, and they used their presence in country schools to shape their individual experiences.
\end{abstract}




\section{Acknowledgments}

This project began a number of years ago, and I owe great debts of gratitude to the people who aided me along the way. My interest in women's history formed during an independent study with Dean Alice Kaylor, the first dean of coeducation at Saint Vincent College, and I later decided to examine women's education in nineteenth-century Pennsylvania for my senior thesis. A number of faculty members and advisors, including Dr. Susan Sommers, Dr. Karen Kehoe, and Dr. Timothy Kelly, read this early work and provided beneficial feedback. I carried this interest to West Virginia University, and I am grateful to have attended the Department of History's Master of Arts Program. I have had the opportunity to work with brilliant professors, and I appreciate all of their lessons, advice, and encouragement.

I am particularly indebted to my thesis chair, Dr. Kenneth Fones-Wolf, for his valuable and insightful feedback. From my first semester at West Virginia University, he has backed this project and has provided me with patient guidance, useful critiques, and unwavering support. I could not have completed this thesis without him, and I appreciate all of his encouragement and dedication during these past three years. I also want to extend my gratitude to the rest of my thesis committee, Dr. Elizabeth Fones-Wolf and Dr. Kimberly Welch for their thoughtful recommendations.

I would also like to express my great appreciation for other professors at West Virginia University who aided me during this process. Dr. Aaron Sheehan-Dean, now at the Department of History at Louisiana State University, guided a seminar paper that expanded my research on rural women's education. Also, Dr. Brian Jara, Senior Lecturer for the Center for Women's and Gender Studies at West Virginia University, provided insightful comments, and more importantly, served as a mentor and friend. 
This project could not have been completed without the assistance of staff members from several historical societies and archives. A number of people helped me find sources and aided me in my research. A special thanks is directed to Joanna Moyar of the Westmoreland County Historical Society, Rae Redd, director of the Eberly Library at Waynesburg University, Jonathan Stayer at the Pennsylvania State Archives, Ella Ann Hatfield at Citizens Library in Washington, Pennsylvania, and the entire staff, especially Anna Schein and Kevin Fredette, of the West Virginia and Regional History Collection at West Virginia University.

Finally, I wish to thank my friends and family for their enthusiastic support. I am forever grateful for Rachel Hochendoner, Kylie McGinnis, Robert Maley and Ashley Shimer for never hesitating to lend an attentive ear or offer advice. I am especially thankful for Richard Morris, who never doubted me. Most importantly, I would like to thank my parents, Barbara and James Perry, for their unending love and constant encouragement. 


\section{Table of Contents}

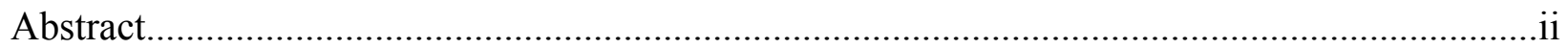

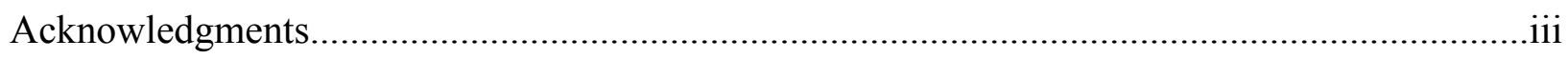

Chapters:

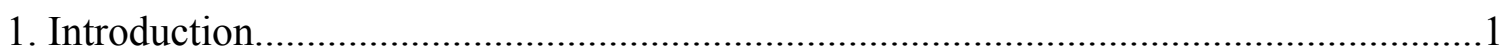

2. Country Schools: The Rise of Public Education in Rural, Mountainous States.............7

3. Rural Administrators: Ideas and Assumptions about Farmwomen's Education...........23

4. Educated Farm Women: The Influence of Public Education on Rural Society...........47

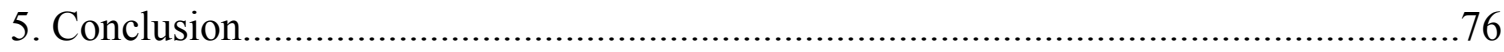

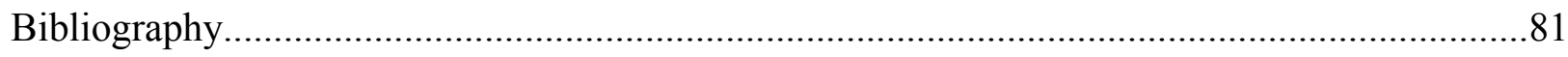




\section{Chapter 1 \\ Introduction}

Bessie Mae Lemley was born near Blacksville, West Virginia, in 1905. Her father was a farmer and her mother was a homemaker who only had a seventh grade education. At a young age, she began to attend a local, one-room schoolhouse and grew to love schoolwork. She also came to admire many of her teachers, particularly Miss Clara Lantz. According to Bessie, Miss Lantz was a "superior teacher" and worked well with the children. Bessie could not help but want to emulate her. Years later, Bessie recalled, "I decided I wanted to be a teacher, when I was in the third grade...I have always been exceptionally interested in school work and tried very hard to reach the goal, that Miss Clara had reached." In fact, Bessie did achieve this goal and was a successful teacher for forty-eight years. She stayed in the Clay District all of her life and taught in elementary schools near Blacksville, West Virginia. By 1940, she supported herself and owned a farm valued at $\$ 3,000$. In the same household lived her widowed mother Mary, her younger sister Georgia, and her niece Lelien Watkins. While working as an elementary school teacher, Bessie continued to take care of her mother until her death in 1973. Bessie never married and died in Blacksville in $1990 .^{2}$

Bessie's account is just one of many rural women's stories that discuss the personal impact of country schools. Not all women who attended rural schools became teachers, but such stories raise questions about the ways in which other countrywomen responded to the rise in public education. Did many, like Bessie, take advantage of new opportunities or did most marry

\footnotetext{
${ }^{1}$ Bessie Mae Lemley, oral history narrative, Folder 3 “Clay Districts, 1921-1982, Box 1 of A\&M 2744 "Monongalia County Schools, 1840-1966,” West Virginia and Regional History Collection, West Virginia University Library, Morgantown, West Virginia; Year: 1910; Census Place: Clay, Monongalia, West Virginia; Roll: T624_1691; Page: 5A; Enumeration District: 0071; FHL microfilm: 1375704; Year: 1940; Census Place: Clay, Monongalia, West Virginia; Roll: T627_4432; Page: 2A; Enumeration District: 31-9.

${ }^{2}$ Year: 1940; Census Place: Clay, Monongalia, West Virginia; Roll: T627_4432; Page: 2A; Enumeration District: 31-9. Ancestry.com. West Virginia, Deaths Index, 1853-1973 [database on-line]. Provo, UT, USA: Ancestry.com Operations, Inc., 2011; Number: 233-62-8235; Issue State: West Virginia; Issue Date: 1956.
} 
and remain on the farm? How did they use expanded educational opportunities to shape their own experiences as wives, mothers, and workers? And ultimately, how did rural women's increased opportunities impact farming families, gender relations, and rural communities?

To answer these questions, this thesis will explore the rise of free, public education and the contest that arose between administrators charged with operating the new schools and the countrywomen who attended them. During the nineteenth century, many rural, mountainous areas saw an increase in the availability of public education as a result of broader social and economic changes. From the Civil War to the early twentieth century, farming communities gradually adopted these common schools, which helped influence rural society's traditional structures of family and community. Historians, however, have rarely examined the public schools' impact on rural women or investigated rural women's responses to the new institution. ${ }^{3}$

While a number of historians study the rise of public education, only a few examine women's education in public schools. Among the first historians to do so were David Tyack and Elisabeth Hansot in Learning Together. ${ }^{4}$ Their study provides a meaningful analysis of the common school movement and its implications for schoolgirls in the nineteenth and twentieth centuries. They depart from the usual historiography, which focused on elite women, and instead explore the ways in which girls from all classes participated in free education. They suggest that rural, public schools were less gender biased than most institutions of the time and gave boys and girls an equal education. ${ }^{5}$ But, they also emphasize the "feminization" of schools, a phenomenon

\footnotetext{
${ }^{3}$ See Bernard Bailyn, Education in the Forming of American Society: Needs and Opportunity for Study (New York: Vintage Books, 1960); Lawrence Cremin, The Transformation of the School: Progressivism in American Education, 1876-1957 (New York: Knopf, 1961); Carl F. Kaestle, Pillars of the Republic: Common Schools and American Society, 1780-1960 (New York: Hill and Wang, 1983); David Tyack, The One Best System: A History of American Urban Education (Cambridge: Harvard University Press, 1974).

${ }^{4}$ David Tyack and Elisabeth Hansot, Learning Together: A History of Coeducation in American Schools (New Haven: Yale University Press, 1990).

${ }^{5}$ Helen Lefkowitz Horowitz, Alma Mater: Design and Experience in the Women's Colleges from Their Nineteenth Century Beginnings to the 1930s (New York: Knopf, 1984); Barbara Miller Solomon, In the Company of Educated
} 
that occurred in the late nineteenth century as more female teachers and pupils flocked to public schools. ${ }^{6}$ According to Tyack and Hansot, predominately male administrators worried that male students did not receive an adequate education and that female teachers would soon overtake the schools as men looked toward industrial labor. While Learning Together supplies us with a convincing argument for administrators' reactions, it leaves the reader wondering about the girls who benefited from this new institution. How did schools influence their attitudes? And what did they do with that education afterward?

Since Tyack and Hansot's study, two monographs have pushed this work. Education and Women's Work by John Rury provides empirical data on the number of women who attended schools and what they did with that education. ${ }^{7}$ He suggests that no simple link existed between women's desire to attend school and the technical training needed for employment. Rather, he argues that some women attended high school to find employment and others attended to participate in school culture. Similarly, Joel Perlmann and Robert A. Margo's Women's Work? provides another quantitative analysis of teachers around the United States. ${ }^{8}$ They refute the previous authors on major points and argue that much of "feminization" occurred in rural, not urban areas. They also suggest that rural districts actively hired more women because they worked for a lower wage and because they began to master the rural school curriculum faster. As schools consolidated, administrators preferred to hire women, forcing men out of work. The

\footnotetext{
Women: A History of Women and Higher Education in America (New Haven: Yale University Press, 1985); Christie Anne Farnham, The Education of the Southern Belle: Higher Education and Student Socialization in the Antebellum South (New York: New York University Press, 1994); Margaret A. Nash, Women's Education in the United States, 1780-1840 (New York: Palgrave Macmillan, 2005); Mary Kelly, Learning to Stand and Speak: Women, Education, and Public Life in America's Republic (Chapel Hill: The University of North Carolina Press, 2006).

6 "Feminization" was first explained by Myra H. Strober and Audri Gordon Lanford, "The Feminization of Public School Teaching: Cross-Sectional Analysis, 1850-1880," Signs 11, no. 2 (Winter, 1986): 212-235.

${ }^{7}$ John L. Rury, Education and Women's Work: Female Schooling and the Division of Labor in Urban America, 1870-1930 (Albany, NY: State University of New York Press, 1991).

${ }^{8}$ Joel Perlmann and Robert A. Margo, Women's Work?: American Schoolteachers, 1650-1920 (Chicago: University of Chicago Press, 2001).
} 
districts inadvertently shifted teaching to a profession that was "sex-typed as women's work."9 While these authors provide valuable insight, their quantitative data raises questions, such as what did women hope to achieve with education? And, how did these new opportunities shape their personal and professional goals?

Aside from quantitative research, only two monographs investigate rural women's perspectives. Kathleen Weiler provides us with a microhistory of rural, female teachers with Country Schoolwomen. ${ }^{10}$ She suggests that women in rural California attained personal satisfaction with their work and felt empowered in a number of ways. According to Weiler, many of them found purpose in children's learning, and several women occupied positions of authority at the state level. Her study has broader implications for understanding rural women's education, but she spends more time discussing their careers than questioning why they were interested in education in the first place. Similarly, Jess Stoddart in Challenge and Change in Appalachia examines settlement schools in rural Kentucky during the early twentieth century. ${ }^{11}$ She reveals that women took on leadership roles as they established settlement schools and played a central role in reform efforts. Yet again, this study focuses on female teachers, not the experience of the majority of rural schoolgirls.

This research leaves us with a lack of perspective. To shed more light on the influence of public education and the ways that rural women navigated the increased opportunities brought about by this new institution, I begin my study with a history of country schools in the Appalachian counties of West Virginia and Pennsylvania. The first substantive chapter describes

\footnotetext{
${ }^{9}$ Joel Perlmann and Robert A. Margo, 107-109.

${ }^{10}$ Kathleen Weiler, Country Schoolwomen: Teaching in Rural California, 1850-1950 (Stanford: Stanford University Press, 1998). For monographs that focus on rural education in other regions, see: Paul Theobald, Call School: Rural Education in the Midwest to 1918 (Carbondale: Southern Illinois University, 1995) and William A. Link, A Hard Country and a Lonely Place: Schooling, Society, and Reform in Rural Virginia, 1870-1920 (Chapel Hill: The University of North Carolina Press, 1986).

${ }^{11}$ Jess Stoddart, Challenge and Change in Appalachia: The Story of Hindman Settlement School (Lexington: The University Press of Kentucky, 2002).
} 
the rise of free, public education as a result of the market revolution and the gradual rise of industrialization, urbanization, and consumerism into the twentieth century. While the two states have some dissimilarities, the social and economic forces of the nineteenth century impacted the region in similar ways. Both enacted public education before the Civil War ended, and local communities incrementally established new schools over the next fifty years. Communities throughout the region followed national patterns of growth and development and saw a gradual increase in attendance throughout the century. The rise of public education provided rural women in this region with expanded opportunities, and a study of this phenomenon reveals the complexity of women's education in rural America.

After reviewing the history of education in rural, mountainous areas, I move to an examination of administrators, the men charged with operating new schools. This chapter provides vital insights into the attitudes of those who were shaping the education experienced by farmgirls and reveals the dual story of women's education. Because this new institution threatened traditional rural society, mostly male administrators assumed the important task of organizing, establishing, and maintaining this new institution. This chapter explores the ways that these men took public commentary and shaped ideas about rural women's education. Circular material, such as The Pennsylvania Farm Journal, The Pennsylvania School Journal, and The West Virginia School Journal, various newspapers, and public documents, such as school reports, meeting minutes, and ledgers, provide a detailed account of administrators' goals for public education and their attempts to limit the range of options available to rural women.

In the last chapter, I use rural women's memoirs to reveal the complex ways that farmgirls navigated between the increased opportunities offered by public education and the traditional notions set forth by mostly male administrators. Oral history interviews, 
correspondence, and diaries offer us a glimpse into the lives of these women often misunderstood by contemporary and modern writers. They show the ways that public education prepared young women for a number of roles as well as the ways that this knowledge enhanced farmwomen's skills and opportunities. In an authentic manner, they reveal the ways that rural women valued public education and shed some light on the extent to which women helped change rural society. 


\section{Chapter 2 \\ Country Schools: The Rise of Public Education in Rural, Mountainous States}

In February 1835, state representative Thaddeus Stevens rose in the Pennsylvania General Assembly to address the issue of public education. The state legislature had passed a Free School Act in 1834, but it was still in doubt at the beginning of the following year. Many new members of the Assembly hoped to weaken the bill by passing a series of amendments, and a few others sought to repeal it outright. To persuade these new members that statewide, public education was vital for progress, Stevens utilized his powerful oratory skills and called for schools that would reach "the poorest child of the poorest inhabitant of the meanest hut of your mountains, so that even he may be prepared to act well his part in this land of freedom..." His speech won over a number of new members, and Stevens was deemed the "savior" of public schools in Pennsylvania. ${ }^{1}$

Nearly thirty year later, delegates in West Virginia took up the same question of public education as they debated the state's first constitution. Deprived for decades of a state funded school system by Virginia slaveholders, politicians at the Constitutional Convention in 1861 formed an education committee and elected Gordon Battelle to serve as committee chairman. Battelle was born in Newport, Ohio, and attended the Marietta Collegiate Institute. In 1840, he received a Bachelor of Arts Degree from Allegheny College in Meadville, Pennsylvania, and shortly after began teaching at the Asbury Academy in Pakersburg, Virginia. He later became the principal at the Northwestern Virginia Academy in Clarksburg. As the education committee chairman, he turned to Reverend Alexander Martin, a professor at Allegheny College, for advice. A few weeks later, Martin presented Battelle with an outline for a public education system,

\footnotetext{
${ }^{1}$ Quoted in Great Leveler: The Life of Thaddeus Stevens by Thomas Frederick Woodley (New York: Stackpole Sons, 1937), 119; Hans L. Trefousse, Thaddeus Stevens: Nineteenth-Century Egalitarian (Chapel Hill: The University of North Carolina Press, 1997), 37-61.
} 
modeled after Pennsylvania. In his notes, Martin called for schools that should be "as free as the air..."2

The debates that surrounded the question of public education, like those spearheaded by Thaddeus Stevens and Gordon Battelle, show the contentious and dynamic nature of free schools in the nineteenth century. During this time, broader social and economic forces shaped the debate among state politicians and influenced leaders to embrace public education. Pennsylvania and West Virginia legislators adopted free public schools in response to the perceived demands of growth and development, but it was unclear how this new education system would impact their largely rural citizens. To gain an understanding of how public schools influenced gender roles and rural society, this first chapter examines the rise of public education in the mountainous areas of Pennsylvania and West Virginia and explores the ways that country schools became the center of rural communities at the turn of the century.

\section{$* * * * *$}

Public education became an integral part of rural society in the nineteenth century as a result of economic and social change that swept across the United States, spreading republican government, Protestant ideals, and capitalism. Changes in the market, new technologies, and advanced communication networks began to connect distant communities and place a focus on market transactions rather than local exchange. Because these forces complicated embedded cultural structures, reformers sought ways to unify society and shape citizens' morality and civic consciousness. To some, public schools were the preferred mechanism. Many reformers believed

\footnotetext{
${ }^{2}$ Quoted in Otis K. Rice and Stephen W. Brown, West Virginia: A History, $2^{\text {nd }}$ ed. (Lexington: The University Press of Kentucky, 1993), 239; Charles H. Ambler, Frances Haney Atwood, and William B. Mathews, eds., Debates and Proceedings of the First Constitutional Convention of West Virginia, (1861-1863), 3 vols. (Huntingdon: Gentry Brothers, 1942), vol. 1, 388-389; George J. Blazier, "The Pioneer Battelles and their Contributions to the Building of Ohio and West Virginia," West Virginia History 15, no. 3 (April 1954): 258-268.
} 
that schools provided a common intellectual and moral culture rooted in Protestantism, republicanism, and capitalism. In short, they would ensure America's destiny. ${ }^{3}$

During the early nineteenth century, many leaders saw reading and writing as central to a democratic society. Patriotic virtue, responsible character, and democratic participation were the ideals for the new republic, but average Americans lacked the means to put these ideals into action if they could not read and write. Zealots of the Second Great Awakening spread their message through pamphlets, government agencies printed numerous reports, and the new Whig party advocated for universal white, male suffrage. According to historian Daniel Walker Howe, “American society needed an educational program synthesizing the civic objectives of Jefferson's Enlightenment with the energy and commitment of the religious Awakening." ${ }^{44}$ Public education, reformers believed, could be that avenue for public participation in government and religion. $^{5}$

Education leaders also saw reading and writing as vital to the burgeoning market economy. With the expansion of markets, the construction of transportation routes, and the mass publishing of new material, the market revolution brought goods and ideas to distant locales. Farmers in the remotest of districts found ways to profit from the economy, and at the same time, the increase in print materials brought new ideas to remote areas. In turn, Americans began to produce for market consumption and less for local exchange. Engaging in these new activities, however, required that people needed to be able to read and write. Recognizing the need to

\footnotetext{
${ }^{3}$ Carl F. Kaestle, Pillars of the Republic: Common Schools and American Society, 1780-1860 (New York: Hill and Wang, 1983), 74-105.

${ }^{4}$ Daniel Walker Howe, What Hath God Wrought: The Transformation of America, 1815-1848 (New York: Oxford University Press, 2007), 453.

${ }^{5}$ Daniel Walker Howe, What Hath God Wrought, 453; Carl F. Kaestle, Pillars of the Republic, 67-72; Michael B. Katz, Reconstructing American Education (Cambridge: Harvard University Press, 1987), 1-25; Lawrence A. Cremin, The American Common School: An Historic Conception (New York: Columbia University Teacher's College, 1951), 1-50; Lawrence A. Cremin, American Education: The National Experience, 1783-1876 (New York: Harper \& Row, 1980), 1-107.
} 
assimilate all Americans, regardless of class, into new economic institutions, reformers called for state-regulated schools that promoted literacy and taught basic mathematical functions. ${ }^{6}$

The market revolution transformed the United States over several decades, but it did so gradually and unevenly. The North, for example, saw transportation growth in the form of turnpikes, steamboats, and canals and technological advancements that led to more wage earners and newly erected factories. The rise in industry and the decreasing reliance on agriculture caused great anxiety for farmers, as growing numbers of rural people migrated to cities looking for new opportunities. At the same time, immigrants continued to come from Europe and settle in growing towns and cities. Urban centers quickly developed in the North as infrastructure and technology expanded, and many northern leaders struggled to maintain social order in these new cities. Seeing this growing and rapidly diversifying population, urban leaders blamed the new migrants for social problems, such as an increase in drinking, violence, and poverty. Education leaders reacted to these changes by maintaining traditional, private academies for elite families and establishing charity schools for the poor. This disparate education, however, did little to reduce class divisions or urban disorder. ${ }^{7}$ Meanwhile, agricultural advocates believed that free, public schools provided necessary skills and knowledge to an increasingly nervous rural population, worried about the fates of their children. As a result, each northern state recognized this perceived need at different times, and most began to gradually adopt common schools

\footnotetext{
${ }^{6}$ Daniel Walker Howe, What Hath God Wrought, 1-7, 233; Charles Sellers, The Market Revolution: Jacksonian America, 1815-1846 (New York: Oxford University Press, 1991), 202-236; Wilma A. Dunaway, The First American Frontier: Transition to Capitalism in Southern Appalachia, 1700-1860 (Chapel Hill: The University of North Carolina Press, 1996), 1-22. Historians Linda Kerber and Jan Lewis identified this social ideology as republican motherhood, which called for female education that went beyond the basic subjects. After the American Revolution, broader society believed that republican mothers should school their families in civic virtue and cement the postRevolutionary generation as full, republican citizens. See Linda Kerber, "The Republican Mother: Women and the Enlightenment — an American Perspective," American Quarterly 28, no. 2 (Summer 1976): 187-205 and Jan Lewis, "The Republican Wife: Virtue and Seduction in the Early Republic," William and Mary Quarterly 44, no. 4 (October 1987): 689-721.

${ }^{7}$ Daniel Walker Howe, What Hath God Wrought, 6, 453; Carl F. Kaestle, Pillars of the Republic, 66; Charles Sellers, The Market Revolution, 366.
} 
starting in the 1820s. These common schools would be tuition-free, tax-supported, and would have common curricula, textbooks, and facilities. Many of the teachers would attend normal schools, where they received training in teacher education, and would pass examinations. ${ }^{8}$

While northern leaders looked toward public schools to cure social ills and maintain order, southerners had far less desire to enact public education. Both planters and yeoman farmers lived sparsely throughout the countryside and relied more heavily on an economy rooted in slavery. The landed aristocracy controlled much of the politics and subsequently the culture of the South, even if the majority of southerners owned few, if any, slaves. These planters had no desire to be taxed to educate poor whites, and they rejected education for their enslaved labor force. For their own children, they hired private tutors or sponsored private academies. As a result, southern state governments, like in Virginia, rarely enacted provisions for common schools. Even for the middling and yeoman farmers, compulsory education seemed like a waste of time and tax money. Many small-scale farmers opposed new taxes, and others were indifferent to change, so many southern states were slow to adopt state-supported education. Instead, rural families relied on subscription schools, dame schools, and charity schools for poor white children. $^{9}$

Despite the sectional divide, farmers in both regions increasingly saw the need for education. Because larger markets made it easier for farmers to sell foodstuffs and buy produced goods, many embraced material and intellectual improvement. Farmers saw new technological

\footnotetext{
${ }^{8}$ Charles Sellers, The Market Revolution, 366-367; Carl F. Kaestle, Pillars of the Republic, 41-70; William Reese, America's Public Schools: From the Common School to 'No Child Left Behind' (Baltimore: Johns Hopkins University Press, 2005), 10-45.

${ }^{9}$ Carl F. Kaestle, Pillars of the Republic, 200-210; Charles Sellers, The Market Revolution, 369; Lawrence A. Cremin, The American Common School, 24-27. In Masters of Small Worlds: Yeoman Households, Gender Relations and the Political Culture of the Antebellum South Carolina Low Country (New York: Oxford University Press, 1995), Stephanie McCurry argues that yeoman farmers supported slavery even if they did not own slaves because they held stake in the culture of mastery. In short, men could be masters of their own household, and they had the potential to become powerful planters. Although she studies the South Carolina low country, McCurry makes a strong case for yeoman political support in a time when few had much to tangibly gain from slavery.
} 
advancements in farming equipment that forced them to seek information and learn certain skills to operate within a market economy. Along with the need for new skills, rural parents saw that their children needed to read, write, and compute for market transactions. Many of these same parents also grew anxious about agricultural productivity and knew that many of their children could not inherit a farm. Consequently, rural neighbors, especially in the North, taxed themselves for even "ramshackle one-room schools" so that children were prepared for other work. ${ }^{10}$ Other local communities established tuition schools or old field schools, which were log cabins built on useless fallow land, for the surrounding families. ${ }^{11}$

Because regions and population areas developed at an uneven pace during the market revolution, Pennsylvania and Virginia adopted public schools at different times. Pennsylvania's economy expanded rapidly as manufacturers capitalized on the state's raw materials and migrants flocked to nascent urban centers. At the same time, railroad companies laid miles of tracks across the Commonwealth, and the General Assembly funded numerous turnpike and canal projects. Leaders saw the states' rapidly expanding population, its complex economic life, and its widening participation of citizens in politics and recognized a need for skilled laborers, practical farmers, and Christian, democratic citizens. Responding to these forces, the General Assembly passed its common school act in 1834 to provide free education to white girls and boys up to the age of $21 .^{12}$

Throughout the 1840s and 50s, districts in Pennsylvania gradually and unevenly established free, public schools. After adoption of the 1834 Free School Act, Pennsylvania

\footnotetext{
${ }^{10}$ Charles Sellers, The Market Revolution, 366.

${ }^{11}$ Carl F. Kaestle, Pillars of the Republic, 13 and 57-65; Sally McMurry, From Sugar Camps to Star Barns: Rural Life and Landscape in a Western Pennsylvania Community (University Park: The Pennsylvania State University Press, 2001), 70; Virginia K. Bartlett, Keeping House: Women's Lives in Western Pennsylvania, 1790-1850 (Pittsburgh: University of Pittsburgh Press, 1994), 121-133.

${ }^{12}$ Philip S. Klein and Ari Hoogenboom, A History of Pennsylvania, $2^{\text {nd }}$ edition (University Park: The Pennsylvania State University Press, 1980), 182-248; James Pyle Wickersham, A History of Education in Pennsylvania, Private and Public, Elementary and Higher (Lancaster: Inquirer Publishing Company, 1886), 78-177.
} 
school officials began to enforce the consolidation of the more than 1,000 community-operated schools into a standard, statewide system of public instruction. While some communities supported public education and agreed to use their local tax dollars to support the new schools, many rural inhabitants resented increased taxes and government involvement. As support gradually broadened at the state level, however, rural communities began to accept public schools. Within the first few years, a number of districts erected one-room schoolhouses, and local school boards began to maintain these institutions based on the available resources. Some communities, however, provided little financial support and few resources, and still others could not find a qualified teacher to lead instruction. Despite these limitations, the number of schools in Pennsylvania continued to grow, and state leaders in the 1850 s called for more improvements, including educational standards, a common curriculum, and instructional credentials. ${ }^{13}$

Public education in Pennsylvania may have been on the rise prior to the Civil War, but the mere idea of enacting free, public schools faced an uphill battle in Virginia. The Virginia elite believed that education was rooted in intellectual advancement for the top of society-men who would serve as political representatives who controlled the future of the state. These eastern politicians had enough political sway over other areas of Virginia, so that when legislators voted to enact public education, these men opted to fund higher education and voted to establish the University of Virginia in $1819 .{ }^{14}$ Meanwhile, politicians from western Virginia recognized the need for common education. Families from this region did not rely on plantation-style farming and slavery like those in the east, but rather small-scale farming and manufacturing. Because

\footnotetext{
${ }^{13}$ Randall M. Miller and William Pencak, eds., Pennsylvania: A History of the Commonwealth (University Park: The Pennsylvania State University Press, 2002), 239; Philip S. Klein and Ari Hoogenboom, A History of Pennsylvania, 242-243.

${ }^{14}$ Carl F. Kaestle, Pillars of the Republic, 200-208; Benjamin Stephen Morgan, Jacob F. Cork, and West Virginia Board of World's fair managers, Columbian History of Education in West Virginia (Charleston, WV: M.W. Donnally, 1893), 5-16; David Tyack and Elisabeth Hansot, Learning Together: A History of Coeducation in American Public Schools (New Haven: Yale University Press, 1990), 46-77; Wilma A. Dunaway, Women, Work, and Family in the Antebellum Mountain South (New York: Cambridge University Press, 2008), 248.
} 
farming families increasingly needed basic reading, writing, and arithmetic, politicians from the west called for free, public schools. While middle-class parents had the option of sending their children to subscription schools, which required a tuition of two or three dollars per child for a term that lasted about two months, poorer families had fewer options for formal education. The state of Virginia provided a literary fund for poor children, but few indigent schools were located in the western counties. Also, most Appalachian families lived too far away to support these schools, and many parents resented this charity and refused to send their children. Farmers could not afford to lose valuable labor, which their children provided, and many others could not afford to pay for the appropriate clothing needed during the winter months. Only Kanawha, Ohio, and Jefferson counties provided free schools for children. As a result, many Appalachian families in Virginia remained illiterate for generations. ${ }^{15}$

Public education finally came to this area when western counties voted to form a new state. The political and cultural line that once divided Virginia had come to alienate the eastern and western counties. When Virginia seceded from the Union at the outbreak of the Civil War, the western counties moved to form a new state. At the 1861 West Virginia Constitutional Convention, Gordon Battelle, who chaired the committee on education, proposed a public education system that modeled those in nearby states. While Battelle was born in Ohio, many other Virginia-born leaders present at the convention also enrolled in northern institutions in nearby states, rather than attend the University of Virginia. This desire to attend out-of-state institutions had deepened the already apparent cultural divide prior to the Civil War, and at school, these soon-to-be West Virginia leaders further relinquished ties to plantation-dominated politics and adopted northern-style, progressive platforms, including the support for common

\footnotetext{
${ }^{15}$ Otis K. Rice and Stephen W. Brown, West Virginia: A History, 68-70, 239; Charles H. Ambler, A History of Education in West Virginia From Early Colonial Times to 1949 (Huntington: Standard Printing \& Publishing Company, 1951), 1-60.
} 
schools. Not only had Battelle attended northern institutions, he had also seen the deficiencies of western Virginia schools first hand. Hoping to follow the surrounding states, Battelle proposed a public education system that would be financed through state appropriations and local taxes and would be operated by a state board of education, a state superintendent, county superintendents, and local administrators. The delegates approved nearly all of the stipulations, and two years later, the state legislature adopted a more detailed plan for public education. ${ }^{16}$

During the first few years of operation, rural schools in West Virginia lacked funding and support, but they soon grew in number. State officials worked to develop schools in the mountainous areas, but they often found that families lived too far away and could not attend meetings to set up a local school. This scant, and often poor, population could not sustain a local school that was funded through property taxes, and because taxes remained high as a result of the War, some communities used state appropriations for rebuilding projects. Also, a number of families similarly resented government involvement and did not understand the new system. As a result, the state was forced to reduce the school term from six to four months. Despite these obstacles, the state established 2,257 schoolhouses by 1870 and hired 2,405 teachers. Of those 2,405 teachers, 641 were women. ${ }^{17}$

Once rural schools became more commonplace, the mountainous states of West Virginia and Pennsylvania advanced public education in similar ways. In the years following the Civil War, both states recognized that not all rural communities had adequate access to public schools. In order to bring education to rural communities, they worked to establish one-room

\footnotetext{
${ }^{16}$ Otis K. Rice and Stephen W. Brown, West Virginia: A History, 239-240; Charles H. Ambler, A History of Education in West Virginia, 130-175; Allison Fredette, “A View from the Border: A Study of Gender and Women's Rights in West Virginia During the Age of Emancipation," (Master's Thesis, West Virginia University, 2008), 1125.

${ }^{17}$ W. R. White, Third Annual Report of the State Superintendent of Free Schools of the State of West Virginia (Wheeling: John Frew, 1867), 22; Otis K. Rice and Stephen W. Brown, West Virginia: A History, 240; Charles H. Ambler, A History of Education in West Virginia, 130-204; Charles. H. Ambler and Festus P. Summers, West Virginia: The Mountain State (Englewood Cliffs: Prentice-Hall, 1940), 298-315.
} 
schoolhouses in the remotest of regions and find other ways to subsidize property tax revenue. West Virginia amended its constitution in 1872, creating a board composed of the governor, superintendent, auditor, and treasurer to manage the state school fund. The amendments also required county sheriffs to collect all related levies, which politicians believed would boost local funding. In Pennsylvania, State Superintendent James P. Wickersham moved quickly after the War to expand public education. He used eminent domain to increase the number of schoolhouses, appointed local superintendents for each school serving over 10,000 inhabitants, and helped to establish schoolhouses in twenty-three school districts that still did not have public education. For example, when the Overfield District in Wyoming County, Pennsylvania, held out against public education, Wickersham personally visited the district "to remove the stubborn prejudices of the people." During his tenure as superintendent from 1866 to 1880, Wickersham helped to promote public schools in Pennsylvania and increase rural access to education. ${ }^{18}$

Gradually, state leaders expanded the school term, which they believed kept children in school and increased attendance. Prior to these new statutes, older boys usually went to school during the winter when their work on the farm was in less demand, and younger children and girls went to school during the summer when their help was not needed. Whenever parents required additional assistance on the farm, they usually pulled their girls to stay home and help. As public education became more popular in rural communities, however, longer terms provided boys and girls more opportunities to attend school. In the 1870s and 80s, Pennsylvania extended the school year from four to five months, and local districts enforced this change. In West

\footnotetext{
${ }^{18}$ James P. Wickersham, A History of Education in Pennsylvania, Private and Public, Elementary and Higher, From the Time The Swedes Settled on the Delaware to the Present Day (Lancaster: Inquirer Publishing Company, 1886), 562, 550-570; Otis K. Rice and Stephen W. Brown, West Virginia: A History, 240-241.
} 
Virginia, most districts met the mandated, four-month term, and some schools met more often, depending on local revenue. ${ }^{19}$

As state leaders continued to promote public education, they also set out to improve the teaching profession. Initially, teachers in Pennsylvania were educated at private academies, which did not properly train teachers. Recognizing the need for special teacher training, the state intervened and passed a Normal School Act, which established specific, teacher-training colleges, in 1857. Over the next several decades, each region began to establish a normal school, so that by 1893 , Pennsylvania had thirteen schools designed to train teachers. These institutions promoted the professionalization of teaching, even if many instructors continued to receive training from private academies or developing high schools. During this same time, state officials approved new teacher examinations in order to remove corruption from the certification process. In 1867, the state passed a new, teacher certification law, which required all individuals wishing to receive a teacher certificate to pass an examination in basic subjects, like reading, writing, geography, and arithmetic. Then in 1870, the state transferred the task of developing teacher examinations from normal school principals to a board of officials appointed by the state superintendent. $^{20}$

Teachers in West Virginia were far less likely to be trained. Because many rural districts could not afford to hire a professionally trained teacher, teachers were often young and inexperienced. The law required instructors to have at least an eighth grade education, and they could elect to attend a teacher institute, which was held for a week or two in the summer. Some

\footnotetext{
${ }^{19}$ David Tyack and Elisabeth Hansot, Learning Together, 46-77; James P. Wickersham, A History of Education in Pennsylvania, xx, 550-560; Otis K. Rice and Stephen W. Brown, West Virginia: A History, 240-241; Charles H. Ambler, A History of Education in West Virginia, 130-204.

${ }^{20}$ Philip S. Klein and Ari Hoogenboom, A History of Pennsylvania, 245, 384-236; James P. Wickersham, A History of Education in Pennsylvania, 560-569; Jurgen Herbst, And Sadly Teach: Teacher Education and Professionalization in American Culture (Madison: University of Wisconsin Press, 1989), 140-160.
} 
counties required a teacher examination, but most county superintendents simply granted a certification when they needed an instructor. After a number of years, West Virginia acknowledged the need for standard certifications and began to require uniform teacher examinations in 1903. Before this time, most rural districts felt that teachers did not have to be highly qualified because most young teachers did not stay in the profession for a long time. Furthermore, the state had little incentive to enforce strict teacher training and certification, and few prospective teachers had the money to attend normal schools. These early programs were more like high schools, rather than a standardized, genuine teacher-training institution. All the same, they required students to pay room and board, and often forced young people to move away from home. It was not until the 1880 s, when a movement rose to establish standard, staterun normal schools to prepare individuals for the profession of teaching. ${ }^{21}$

Country schools continued to feel the pressure to adapt as broader social and economic forces threatened to reshape rural society. By the turn of the century, state and local school administrators implemented graded schools, high schools, and advanced curriculum to suit an increasingly complex society. Large-scale businesses and a rising consumer culture brought together rural and urban communities as it simultaneously threatened the traditional values of rural society. State leaders became increasingly aware of changes in the daily lives of rural communities and in the broader American culture, and as a result, education reformers reacted by updating their schools to reflect these larger societal shifts. ${ }^{22}$

In the late nineteenth century, education reformers set their sights on enacting and enforcing compulsory education. During this time, many officials reflected on the progress of

\footnotetext{
${ }^{21}$ Otis K. Rice and Stephen W. Brown, West Virginia: A History, 241-242; Charles H. Ambler, A History of Education in West Virginia, 130-204.

${ }^{22}$ Lawrence A. Cremin, American Education: The Metropolitan Experience, 1876-1980 (New York: Harper and Row, 1988), Part II: The Progressive Nation; Hal S. Barron, Mixed Harvest: The Second Great Transformation in the Rural North, 1870-1930 (Chapel Hill: The University of North Carolina Press, 1997), 43-77.
} 
public education and found that rural children still did not attend school regularly. Hoping to improve attendance at country schools, school officials called for state-mandated, compulsory attendance. In 1891, the West Virginia legislature passed its compulsory education act, which required children between the ages of eight and sixteen years to attend school and instructed boards to appoint truancy officers. Only working children who could read and write were permitted to leave school. According to the West Virginia state superintendent of schools, compulsory laws were a major hardship for the state to enforce, but local communities began to gradually implement the requirements. ${ }^{23}$ The Pennsylvania General Assembly mandated compulsory education in 1901, using a similar law to that of West Virginia. Local districts also had problems with enforcement, but attendance levels steadily increased throughout the early twentieth century. ${ }^{24}$

State-level administrators also sought to extend urban-style education to rural communities by consolidating common schools and establishing graded elementary schools. In both states, administrators first brought graded one-room schools to villages and densely settled locales. As farming communities improved roads and transportation networks, education reformers looked toward these sparsely populated communities, which usually had schools that taught a number of scholars of various levels. Consolidating these rural common schools into graded elementary schools, they argued, would save the district money as well as improve the quality of education. They believed that in a graded elementary school, teachers devoted more time to age-appropriate learning and personal time with each child. They also insisted that

\footnotetext{
${ }^{23}$ State Superintendent of Schools, The History of Education in West Virginia, revised ed. (Charleston: Tribune Printing Company, 1907), 54.

${ }^{24}$ Nathan C. Schaeffer, Report of the Superintendent of Public Instruction of the Commonwealth of Pennsylvania for the Year Ending June 3, 1901 (Harrisburg: William Stanley Ray, 1901), vii-viii; M. P. Shawkey, Biennial Report of the State Superintendent of Free Schools of West Virginia for the Two Years Ending June 30, 1916 (Charleston: Tribune Printing Co, 1916), 114; Nathan C. Schaeffer, Report of the Superintendent of Public Instruction of the Commonwealth of Pennsylvania for the Year Ending July 1, 1918 (Harrisburg: J.L.L. Kuhn, 1918), 630; Charles H. Ambler, A History of Education in West Virginia, 205-273.
} 
education in graded schools led students to the graded high school and possibly college or university studies. To gain support from farming communities and local leaders, state governments campaigned for the projects in hopes of improving rural schools. They also needed to support transportation, as more students came from farther away to attend consolidated schools. $^{25}$

At the same time, state administrators intended to establish rural high schools. Like graded elementary schools, public high schools first started to appear in towns and villages, but education reformers sought to bring the advantages of secondary education to rural communities. According to West Virginia state superintendent Virgil A. Lewis, "A Country High School is the logical solution of the question of the unification of the State's educational work, and its establishment is entirely practicable. ${ }^{26}$ In 1892 , there were only seventeen free high schools in the state for 200,000 children. Lewis and other administrators at the county and local levels feared that teenagers had no professional training and could not market themselves for jobs that required an advanced set of technological skills. Their state funding and promotion, however, did encourage more counties to establish high schools, and a decade later West Virginia boasted forty-two public high schools. ${ }^{27}$ Centralized townships in Pennsylvania similarly established

\footnotetext{
${ }^{25}$ State Superintendent of Schools, The History of Education in West Virginia, 135-146; Benjamin Stephen Morgan, Jacob F. Cork, and West Virginia Board of World's fair managers, Columbian History of Education in West Virginia (Charleston, WV: M.W. Donnally, 1893), 20-26; James P Wickersham, A History of Education in Pennsylvania, 534-536; Nathan C. Schaeffer, Report...Ending June 3, 1901, 36-234.

${ }^{26}$ Virgil A. Lewis, Biennial Report of the State Superintendent of Free Schools of the State of West Virginia For the Years 1893 and 1894 (Charleston: Moses W. Donnally, public printer, 1894), 21.

${ }^{27}$ Thomas C. Miller, Biennial Report of the State Superintendent of Free Schools of West Virginia For The Two Years Ending June 30, 1902 (Charleston: The Tribune Printing Company, 1903), 29; Virgil A. Lewis, ed, Biennial Report... For the Years 1893 and 1894, 138-160.
} 
high schools after laws in 1895 and 1901 expressly authorized them. With this increase in public schools came a decline in enrollment in a number of private academies and seminaries. ${ }^{28}$

In addition to systemic changes, administrators sought curriculum development in hopes of preparing students who were not headed to college. For one, public high schools continued to hold the important goal of training teachers for elementary schools. At many high schools, students took standard teacher education courses and then passed a teacher examination. Many more schools, however, were not properly preparing teachers, and so by the turn of the century, school officials encouraged future educators to attend a newly developed state normal school or university. ${ }^{29}$ The second main objective for public high schools was to prepare students for other careers and life-long learning. At the Huntingdon, Pennsylvania, high school, for example, students could choose from four programs: classical, which prepared pupils for college; scientific, which provided a general education; business, which prepared students for bookkeeping and similar careers; and normal, which trained teachers. Regardless of which course they chose, all students took similar courses in spelling, arithmetic, Latin, rhetoric, literature, and geometry. Then, they took electives that suited their career paths. ${ }^{30}$

At the high school level, this curriculum development also included manual training and domestic science courses after the turn of the century. As rapid and extensive industrial expansion came to Pennsylvania and West Virginia communities, local leaders called for practical and vocational education. High school curricula now included manual training, which

\footnotetext{
${ }^{28}$ James P. Wickersham, A History of Education in Pennsylvania, 545-547; James Mulhern, A History of Secondary Education in Pennsylvania (Philadelphia: James Mulhern, 1933), 510; Charles H. Ambler, A History of Education in West Virginia, 404-411.

${ }^{29}$ James Mulhern, A History of Secondary Education in Pennsylvania, 520-525; Edward Stevens, Jr., Michael Katz, and Maris A. Vinovskis, "Forum: The Origins of Public High Schools," History of Education Quarterly 27 (Summer 1986): 241-258.

${ }^{30}$ Huntingdon Public Schools, Rules, Regulations, and Course of Study, Adopted August 16, 1897 (Huntingdon, PA: J. L. Rupert, Book, and Job Printers, 1897), 33-36, School Records, Box 3, Huntingdon County Historical Society Archives, Huntingdon, PA.
} 
prepared men for skilled labor. In these programs, male students studied the classic subjects for a part of the time, and for the remaining time worked "in the shops or working-rooms." 31 Women also benefited from domestic science courses that appeared to legitimize traditional female work. These programs served the purpose of preparing women for domestic careers, in addition to married life. $^{32}$

These incremental changes improved the educational system in mountain communities, and over time, more local people came to embrace their country schools. According to West Virginia state superintendent Virgil A. Lewis, "The Country School is the strength of the Country Home and is, therefore, the strength of the Nation and State. What an interest, therefore, centers in the Country school! How great its influence upon our institutions and upon this and succeeding generations. ${ }^{, 33}$ By the twentieth century, local one-room schoolhouses became an integral part of rural society, and the Country Life Movement supported these changes. On a national scale, this social movement sought to improve rural life by preserving the traditional rural lifestyle, addressing poor living conditions and social ills, and bringing progressive reforms to improve the efficiency of American agriculture. Many of these reformers were not farmers, but were urbanites, professionals, teachers, and government employees. At the same time, oneroom schoolhouses began to operate as a backbone for many rural communities and served as an education center for children and adults. Outside of instruction, they provided a venue for various meetings, including church services, debates, and socials. ${ }^{34}$

\footnotetext{
${ }^{31}$ James Mulhern, A History of Secondary Education in Pennsylvania, 534; State Superintendent of Schools, The History of Education in West Virginia, 102 and 186-190.

${ }^{32}$ State Superintendent of Schools, The History of Education in West Virginia, 102-105; James Mulhern, A History of Secondary Education in Pennsylvania, 528-539.

${ }^{33}$ Virgil A. Lewis, Biennial Report...For the Years 1893 and 1894, 21.

${ }^{34}$ Hal S. Baron, Mixed Harvest, 68-77; David B. Danbom, "Rural Education Reform and the Country Life Movement, 1900-1920," Agricultural History 53, no. 2 (April 1979): 462-474; Liberty Hyde Bailey, The CountryLife Movement in the United States (New York: The Macmillan Company, 1920); William L. Bowers, The Country Life Movement in America, 1900-1920 (Port Washington: Kennikat Press, 1974).
} 


\section{Chapter 3 \\ Rural Administrators: Ideas and Assumptions about Farmwomen's Education}

In a 1974 interview, retired schoolteacher Gladyce Nunn explained that "the purpose of education, I think, when I started to school was to learn as much as you could...but then women were suppose to get married and take a role of home, mother and homemaker. They didn't work outside of the home very much so really, I suppose that particularly a girl's education back in those days was just so she in the future plans could help plan her children..." Over time, as she obtained her education and eventually became a teacher, she saw administrators' opinion change. She believed that "the aim of education" evolved to produce women who could claim to be independent members of society, people "who won't have to depend on somebody else to take care of them."

Gladyce Nunn identified an important cultural shift in the way that administrators viewed farmwomen's education from the nineteenth to the early twentieth century. The men charged with operating an expanded public school system that reached into mountainous areas after the Civil War had to overcome not only their own predispositions but also a good deal of public commentary to give Nunn the sort of education she valued. This chapter examines the evolution of the ideas and assumptions about female education that were held by school administrators in rural western Pennsylvania and West Virginia to reveal the ideas about proper womanhood that farmgirls confronted when in school.

\section{$* * * * *$}

School administrators in the second half of the nineteenth century confronted culturally embedded notions of the proper role of women. These notions surfaced after significant debate

\footnotetext{
${ }^{1}$ Gladyce K. Nunn, interviewed by Joe Woolwine, February 23,1974, transcript, p. 16, Marshall University Oral History of Appalachia, West Virginia and Regional History Collection, West Virginia University, Morgantown, WV [hereafter cited as WVU].
} 
over the value of including farmgirls in the new educational opportunities that were represented in the common school system. These debates infiltrated rural society through such materials as newspapers and magazines, which circulated among rural people. Even those who were illiterate could attend local speeches given by a politician or administrator. These sources provide a rich context of ideas about education and the ways in which nineteenth century rural people saw it through a gendered lens. They did not always agree, but these early authors came to a general consensus about rural women's education. Most often, they told countrywomen to be sensible, domestic, and moral. ${ }^{2}$ Proponents of this theme rationalized their opposition to women's education. Even authors that supported common schools often deprecated female education. For example, Horace Mann, considered by many the "father of the common school movement," claimed that women were physically different from men and for that reason had less intellectual capacity than them. ${ }^{3}$ His ideas spread throughout rural communities via newspapers and told farmers that they could send their sons for advanced schooling but not their daughters. ${ }^{4}$

Even many female education advocates promoted a limited role for women's schooling.

Catharine Beecher, who wrote extensively on female education, abolition, and social ills, advised

\footnotetext{
${ }^{2}$ In "The Ideal Woman in the Antebellum South: Lady or Farmwife?" (The Journal of Southern History 46, no. 3 [August 1980]: 405-418) D. Harland Hagler argues that the public expected the antebellum farmwife to be sensible and practical as well as, "perfect wives, devoted mothers, and impeccable homemakers" (406). His analysis rests heavily on prescriptive texts, not necessarily on the reality of farm life for rural women, and he focuses on elite southern culture, not necessary Virginia or rural Pennsylvania. Also, his work furthers that of Barbara Welter, who identifies the cult of true womanhood as the dominant ideology for elite, white women in the antebellum era. See Barbara Welter, "The Cult of True Womanhood: 1820-1860," American Quarterly 18, no. 2 (Summer 1966): 151174.

${ }^{3}$ Horace Mann, A Few Thoughts on the Powers and Duties of Woman, Two Lectures (Syracuse: Hall, Mills, and Company, 1853), 17; Daniel Walker Howe, What Hath God Wrought: The Transformation of America, 1815-1848 (New York: Oxford University Press, 2007), 453. Horace Mann (1796-1859) was a member of the Massachusetts House of Representatives from 1827 to 1833, a member of the Massachusetts Senate from 1834 to 1837, and a member of the US House of Representatives from 1848 to 1853.

${ }^{4}$ Horace Mann, "Invitation to the National School Convention," reprinted in Jeffersonian Republican, July 18, 1850; "Horace Mann on Labor," The Mountain Sentinel, August 8, 1850; "Ignorant Voters," The Columbia Democrat, September 17, 1845.
} 
women to remain within the confines of Victorian womanhood. ${ }^{5}$ In Suggestions Respecting

Improvements in Education, Beecher argued that women needed instruction in "those habits and employments which relate to a woman's domestic pursuits." She in no way demeaned

housework; rather, she attempted to improve it and persuade her audience that women's work in the home was important. ${ }^{6}$ In fact, household duties, Beecher argued, were essential for family members' wellbeing. To her, women controlled the family's spirituality, nutrition, education, and health, so they needed a well-rounded education with a focus on the sciences and mathematics. Housework, raising a family, and cooking required certain skills like knowing basic chemical reactions, systems of the body, and finance. In short, educated women had the basic skills to perform well in the home. ${ }^{7}$ These ideas were accessible to rural people by way of local newspapers that reprinted her writings. The Sunbury American and Shamokin Journal of Sunbury, Pennsylvania, ran an excerpt from her Treatise on Domestic Economy, which claimed that studying too much was harmful to the health of American women. Nevertheless, she advocated for appropriate education, such as making the home run smoother, learning about personal anatomy and health, and rearing children. According to Beecher, this knowledge would give women the power to run their homes efficiently and improve their lives. ${ }^{8}$

Some advocates stressed female education to create a more moral society. In his address to the Susquehanna Female College, Rev. E. W. Hutter associated intellect with piety. For him, proper womanhood included practical and religious knowledge. He validated women's education

\footnotetext{
${ }^{5}$ Kathryn Kish Sklar, Catharine Beecher: A Study in American Domesticity (New Haven, CT: Yale University Press, 1973), Parts 2 and 3; John Rury, Education and Women's Work: Female Schooling and the Division of Labor in Urban America, 1870-1930 (Albany: State University of New York Press, 1991), 14-16.

${ }^{6}$ Catharine E. Beecher, Suggestions Respecting Improvements in Education, Presented to the Trustees of the Hartford Female Seminary, and Published at their Request (Hartford: Hudson and Skinner, 1829), 155. Catharine Esther Beecher (1800-1878) was an advocate for women's education and opened the Hartford Female Seminary. ${ }^{7}$ Beecher, Suggestions Respecting Improvements in Education, 58.

${ }^{8}$ Catharine E. Beecher, "Physical Debility of American Women," reprinted in Sunbury American and Shamokin Journal, May 21, 1842; Catharine E. Beecher, A Treatise on Domestic Economy For the Use of Young Ladies At Home and At School, revised edition (Boston: Thomas H. Webb 1843).
} 
by assuring graduates that schooling could be used for moral and domestic purposes. He suggested that the girls use all levels of "Christian benevolence," such as feeding the hungry, instructing the ignorant, and clothing the naked. Then when they married, he insisted that they use what they learned at school in the home. ${ }^{9}$ Magazines in western Virginia reinforced the goal of improving morality. Published in Harpers Ferry, The Ladies' Garland promoted knowledge as synonymous with "human virtue and human happiness." ${ }^{10}$ Women who attended school took advantage of refined subjects, like literature, grace of manners, polish, and domestic duties. For these authors, schools that provided classical literature, domestic arts, and needlework molded young women into respectable ladies. According to school catalogues, many women who could afford a private education did take on these responsibilities. Graduates of the Washington Female Seminary in Washington, Pennsylvania, worked as teachers, librarians, and missionaries. They also volunteered with charities to help the urban poor, rural "mountaineers," and indigent children. ${ }^{11}$

While journals, speeches, and magazines promoted female education as moral and domestic, authors also realized that the majority of rural women could not share in these advantages of education. Even if, as The Ladies' Garland claimed, "education has extended itself through all ranks of female society,” this was not the reality for rural women. Most had few opportunities to attend school and "refine" skills in any way. ${ }^{12}$ Instead, when these authors spoke of rural women's education specifically, they more often prescribed schooling as a way for

\footnotetext{
${ }^{9}$ E. W. Hutter, Female Education: Its Importance, The Helps and the Hindrances: Address Delivered Before the Faculty and Students of the Susquehanna Female College, at Selinsgrove, PA (Baltimore: T. Newton Kurtz, 1859), 6-20.

10 “Female Education," The Ladies' Garland 4, no. 32 (January 19, 1828): 127.

${ }^{11}$ Alumnae Association, Washington Seminary Alumnae Register, 1837-1924 (Washington: Observe Job Rooms, 1924) in Folder Washington Female Seminary 1837-1924, in the Washington Female Seminary Collection at Citizens Library, Washington, PA.

12 “The Monitor: Influence of Female Education," The Ladies' Garland 3, no. 43 (December 2, 1826): 170; Wilma Dunaway, Women, Work, and Family in the Antebellum Mountain South (New York: Cambridge University Press, 2008), Part 2.
} 
mothers to educate their children on the farm. An author in The Lewisburg Chronicle of Lewisburg, Pennsylvania, saw children as the future of the republic. He advised parents to instruct their children in the ideals of personal freedom and liberty. As a result, he argued, the beginning of youngsters' education started with the parents. He saw women as men's companions who also deserved an equal education. He did "not believe in educating the boys and not the girls for the pursuits of farm life. Every farmer wants a wife as intelligent as himself." Parents' next step was to send their children to school instead of giving them a rudimentary education on the farm. For the author, "education of young men and women for the pursuit of farm life is just as important as their education for teachers, or for any other profession or position. ${ }^{, 13}$ His argument appears more egalitarian than many others at the time, but he still prescribed domestic roles to guide farmwomen.

The Lewisburg Chronicle reinforced its message with a story about a farm girl who loved to learn. From a young age, Mary Marvel learned to read and spell from her mother, but she was often too busy with farm work to keep up with her daughter. Because Mary wanted to study advanced subjects that her mother could no longer teach her, Mary enrolled at the local one-room schoolhouse. There, Mary and her neighbor Julius became fast friends, but eventually, Julius went on to study law, leaving Mary to continue her schooling at the one-room schoolhouse. When Julius returned a few years later, he noticed that Mary's health had deteriorated from studying eight to ten hours a night. Despite her ill health, Julius fell madly in love with Mary and proposed shortly after his return. Hoping to improve her health, Julius gave Mary a book on physiology and the human body, and later as a married couple, they moved to Indiana for the fresh air. The title of this story, "Love, vs. Health," implies that Mary chose her love of learning

13 “Will It Pay?” Valley Farmer reprinted in The Lewisburg Chronicle, October 15, 1858. 
over her wellbeing, but Julius knew how to incorporate both. Rather than disapprove of her studying, Julius encouraged her by giving her books, and all the while kept her health in mind. ${ }^{14}$

Although most antebellum voices in the debate over women's education emphasized Victorian domesticity, some commentators hoped for a future of women in the home, church, and school. One author in The Mountain Sentinel of Ebensburg, Pennsylvania, criticized homes "where fashion sits supreme," and called for women's education that cultivated independence and self-awareness. ${ }^{15} \mathrm{He}$ did not want women to be obedient, polished wives, so that their conversations "would be worth more to their husbands, a thousand times over, than all the music and dancing and drawing that were ever flourished forth from the academies." He believed that women should have substance, beyond the frivolities of fine dress, dancing, or art. As for the men, they should engage educated women for their own worth, in a conversation of equals. Rather than highlighting women's need for domesticity and frivolities, he reasoned that women also needed knowledge; knowledge gained at school.

By mid-century, fewer writers questioned women's education, but the increase of educated women in Pennsylvania riled some men who feared its impact on rural society. ${ }^{16}$ Rev. William M. Cornell of Franklin County, Pennsylvania felt strongly about the "nonsense" of contemporary female education, enough so to write to the local paper. In the September 4, 1861 issue of the Valley Spirit, he insisted that an educated woman was "fit for nothing but to be the crooked-spined, debilitated, nervous, fidgety thing that she is." ${ }^{17}$ According to Cornell, the

\footnotetext{
${ }_{15}^{14}$ C.M. Sedgwick, "Love, vs. Health,” Lewisburg Chronicle, July 30, 1851.

15 "Future of Woman," The Mountain Sentinel, July 28, 1853.

${ }^{16}$ In $1850,190,952$ girls went to Pennsylvania common schools. In 1857 , that number increased to 245,849 girls, or roughly $45 \%$ of pupils. See James P. Wickersham, Report of the Superintendent of Common Schools of the Commonwealth of Pennsylvania, For the Year Ending June 4, 1866, (Harrisburg: Singerly \& Myers, 1867), 317; A. L. Russell, Seventeenth Annual Report of the Superintendent of Common Schools of Pennsylvania, For the School Year Ending June 1, 1850 (Harrisburg, 1851), 4..

${ }^{17}$ William M. Cornell, "Education of Females," Chambersburg Valley Spirit, September 4, 1861, The Valley of the Shadows Project, Web, (accessed February 8, 2012).
} 
public should only accept educated women so long as they learned to be domestic angels with a strict sense of morality.

The Civil War posed new challenges for school administrators. In Pennsylvania, the war did little to halt education, and women enrolled steadily and accounted for more of the teaching positions. Many schoolgirls performed well in this new space, leading one Pennsylvania administrator to remark, "females as a rule succeed better than males in common schools."18 Some administrators believed that this was a good sign for the future of public education. In Lancaster County, Pennsylvania, superintendent David Evans felt that "there would be rapid and continuous progress in the schools" after the War. ${ }^{19}$ He insisted, "there is every reason to believe that such expectation will be realized." ${ }^{20}$ Because many of the rural counties in Pennsylvania remained insulated from the ravages of war seen in states like Virginia, local districts looked to the future almost immediately after Appomattox, and that future included women.

Administrators in the new state of West Virginia faced different trials. The formative state legislature, under the influence of men who wanted to model the state after Pennsylvania and Ohio, immediately enacted a law that required each township to elect commissioners and to administer common schools funded by local property taxes. Many legislators felt that the free school system provided opportunities that few girls and boys had under the Commonwealth of Virginia. At the same time, they hoped that teachers would show new students how to be productive, moral, and patriotic citizens. Some new public schools consolidated with

\footnotetext{
${ }^{18}$ Charles R. Coburn, Report of the Superintendent of Common Schools of Pennsylvania, For the Year Ending June 4, 1863 (Harrisburg: Singerly \& Myers, 1864), 60; James P. Wickersham, Report...Ending June 4, 1866, 317; Henry C. Hickok, Report of the Superintendent of Common Schools of Pennsylvania, For the Year Ending June 2, 1857 (Harrisburg: A. Boyd Hamilton, 1858), 133. In 1857, 245,849 girls (or roughly $45 \%$ of pupils) went to Pennsylvania commons schools. In $1866,304,521$ girls (or roughly $47 \%$ of pupils) attended school.

${ }^{19}$ James P. Wickersham, Report of the Superintendent of Common Schools of the Commonwealth of Pennsylvania, For the Year Ending June 3, 1867 (Harrisburg: Singerly \& Myers, 1868), 44; Charles R. Coburn, Report ...Ending June 4, 1863, 168.

${ }^{20}$ James P. Wickersham, Report...Ending June 3, 1867, 144.
} 
subscription schools and dame schools, once conducted in women's homes. ${ }^{21}$ In other communities, the law confronted a poor citizenry that was unhappy about the taxes necessary to build and staff schools. ${ }^{22}$ In Kanawha County, West Virginia, school superintendent A.I. Cunningham explained, "we have many school houses to build, as the churches and school houses were more or less destroyed during the rebellion."23 A few communities refused to implement any changes because they lacked money and did not understand the new system. ${ }^{24}$ Many rural families also balked at the mandate to erect schools because they required taxes and took away farm labor. Despite these drawbacks, West Virginia schools emerged with surprising celerity. The Clinton District in Monongalia County, West Virginia, for example, had only eight schoolhouses in 1863 , but by 1872 , boasted fifteen sub-districts with numerous one-room schoolhouses in each. ${ }^{25}$ During this time, schools, teachers, and the curriculum were new for virtually all of the middling and poorer class farming families.

In addition to providing more opportunities for schoolgirls, the War also gave Pennsylvania and West Virginia women the chance to teach as the supply of male teachers dwindled, and their subsequent debates about female teachers informed their perception of female education as a whole. For example, farmwomen could now serve as leaders in rural classrooms. In Butler County, Pennsylvania, so many male teachers enlisted in the War that women held seventy-five percent of teaching positions in 1863. The superintendent explained, "This, by no means is detrimental to the youth." In fact, "I have no hesitancy in saying, that, in

\footnotetext{
21 "Battelle District," Folder 1, Box 1; "Cass District," Folder 2, Box 1; "Clay District," Folder 3, Box 1; "Clinton District," Folder 4, Box 1; "Grant District," Folder 5, Box 1; "Morgan District," Folder 6, Box 1; "Union District," Folder 7, Box 1, A\&M 2744, "Monongalia County Schools. Reminiscences," WVU.

${ }^{22}$ W. R. White, Third Annual Report of the State Superintendent of Free Schools of the State of West Virginia (Wheeling: John Frew, 1867), 22.

${ }^{23}$ W. R. White, Second Annual Report of the State Superintendent of Free Schools, of the State of West Virginia (Wheeling: John Frew, 1866), 20.

${ }^{24}$ W.R. White, Second Annual Report of...West Virginia, 20.

25 "Clinton District," Folder 4, Box 1, A\&M 2744, "Monongalia County Schools. Reminiscences," WVU.
} 
orderly arranged school rooms, good classifications, address, and progress of the pupils, the schools under the care of females were not inferior to others." ${ }^{26}$ By 1865 , women were the majority of Pennsylvania's teachers, and in West Virginia, 216 women taught in the newly formed public schools, compared to only 171 men. ${ }^{27}$ In fact, there was "a scarcity of male teachers" in West Virginia during the entire war. ${ }^{28}$

Because more women taught during the War, attitudes began to shift and districts looked for women to fill men's places. To support this cultural transition, administrators changed their published opinions, from doubting women's abilities to needing their support. For some, women were "peculiarly fitted for the vocation," because their biological difference made them better nurturers. As male administrators needed women's help, they saw nurturing qualities as suitable to the classroom. Another administrator hoped to see "their continued and increasing success an indefinite extension of the too limited sphere in which woman has heretofore been allowed to move and act and bless." ${ }^{29}$ His suggestion is a far cry from most commentators' writing three years prior.

After the War, many Pennsylvania administrators continued to discuss female teachers' success. Several believed that women had a natural ability to teach because they deemed women inherently gentle, effective, nurturing, and industrious. ${ }^{30}$ According to one superintendent, female teachers even tidied up better than male teachers: "The rooms, generally, were neat and

\footnotetext{
${ }^{26}$ Charles R. Coburn, Report ...Ending June 4, 1863, 47-48.

27 "West Virginia: Comparative School Statistics, 1865-1892," in A\&M 842, "West Virginia School and Agricultural Statistics," WVU; W.B. Cutright, The History of Upshur County, West Virginia, From its Earliest Exploration and Settlement to the Present Time (Buckhannon, WV, 1907), 266-276.

${ }^{28}$ W.R. White, Second Annual Report of...West Virginia, 19; James P. Wickersham, Report...Ending June 4, 1866 , 317.

${ }^{29}$ Charles R. Coburn, Report ...Ending June 4, 1863, 73.

${ }^{30}$ James P. Wickersham, Report...Ending June 3, 1867, 260; James P. Wickersham, Report of the Superintendent of Common Schools of the Commonwealth of Pennsylvania, For the Year Ending June 3, 1872 (Harrisburg: B.

Singerly, 1872), 146.
} 
clean, especially those in charge of female teachers. ${ }^{.31}$ Others were willing to hire women year round to improve the quality of education. They found that hiring men in the winter and women in the summer was inefficient, as teachers had little time to settle and improve upon students' existing knowledge. ${ }^{32}$

Another advantage was financial. School districts paid women considerably less than men, even "when the work is done equally." ${ }^{, 33}$ Occasionally, a few Pennsylvania administrators criticized wage disparity. As early as 1868 , one superintendent observed that women had the potential to be administrators. ${ }^{34}$ This belief, however, was not the norm. Directly after the War, Pennsylvania administrators showed support for female teachers, but they often returned to traditional standards of domesticity and morality to validate the upended gender roles. Instead of using traditional notions of womanhood to support women's role in the home, administrators used these ideas to catapult women into new professions, only after they deemed it appropriate. At the same time, most administrators refused to pay female teachers equal wages for jobs they were believed to be equal for and better at. ${ }^{35}$

Even though many administrators shifted their attitudes toward female teachers, some attempted to return to their traditional agenda. Some superintendents were not ready to entrust discipline to women, especially now that they did not free up men for service. ${ }^{36}$ As one superintendent put it, "I am not prepared to consider female teachers equal in every respect to males. The gift, Napoleon, the god-like power of commanding, does not seem to be theirs by

\footnotetext{
${ }^{31}$ James P. Wickersham, Report...Ending June 3, 1867, 260.

${ }^{32}$ James P. Wickersham, Report...Ending June 3, 1867, 160.

${ }^{33}$ James P. Wickersham, Report...Ending June 3, 1867, 116 and 260-261; Joel Perlmann and Robert A. Margo, Women's Work?: American Schoolteachers, 1650-1920 (Chicago: University of Chicago Press, 2001), 86-89.

${ }^{34}$ James P. Wickersham, Report...Ending June 3, 1867, 116, 200, and 260-261.

${ }^{35}$ James P. Wickersham, Report...Ending June 3, 1867, 260; James P. Wickersham, Report of the Superintendent of Common Schools of the Commonwealth of Pennsylvania, For the Year Ending June 3, 1872 (Harrisburg: B. Singerly, 1872), 146.

${ }^{36}$ James P. Wickersham, Report...Ending June 3, 1867, 49.
} 
nature." Coming out of the most devastating war of their generation, almost all men identified commanding and discipline as masculine traits. ${ }^{37}$ Male teachers could attain, "the eagle's flight," whereas female teachers sat as inert, "timid doves.",38 The eagle connoted war, power, and masculinity; the dove represented peace, purity, and womanhood. Because men's place in the public sphere made them eligible for citizenship and war, they knew how to discipline and to inculcate the next generation. According to the superintendent, if women became teachers, American society and citizenship would deteriorate because they lacked firm discipline. His, along with the contrary dialogue, shows that male leaders in Pennsylvania viewed women's roles in different ways, but their discussions laid the groundwork for later generations to reconceptualize gender roles in rural society.

Women were part of West Virginia's developing teaching ranks from the beginning. Some administrators responded positively, but many masked this support with domestic portrayals of women. For example, one expressed admiration for "their superior social and moral qualities for training youth. ${ }^{, 39}$ While this male superintendent approved of female teachers to the degree that they satisfied their natural role, by 1868 , men outnumbered women by two to one. ${ }^{40}$ Unlike many in Pennsylvania, a number of administrators in West Virginia did not accommodate female teachers and new gender roles until decades later. In the school reports and The West

\footnotetext{
${ }^{37}$ According to LeeAnn Whites, elite southerners struggled to reconstruct and make order of white manhood and womanhood after defeat. Former masters felt threatened by the new social order, so they looked toward the domestic sphere where they could return to patriarchal heads and protectors of women and children. In West Virginia, administrators seem less afraid of these racial shifts than planters in Georgia because many of them were nonslaving holding, subsistence farmers. They as well as Pennsylvanians did fear, however, uprooted gender roles because the new norms directly affected their power structure that they knew before the war. Keeping educated women in particular roles kept men in power and maintained job opportunities outside of the farm. See LeeAnn Whites, The Civil War as a Crisis in Gender: Augusta, Georgia, 1860-1890 (Athens: University of Georgia Press, 1995), 96-160; LeeAnn Whites, Gender Matters: Civil War, Reconstruction, and the Making of the New South (New York: Palgrave Macmillan, 2005); Jane Turner Censer, The Reconstruction of White Southern Womanhood, 1865 1895 (Baton Rouge: Louisiana State University Press, 2003).

${ }^{38}$ James P. Wickersham, Report...Ending June 3, 1867, 49.

${ }^{39}$ W. R. White, Third Annual Report of...West Virginia, 21.

${ }^{40}$ In 1868, 1290 men taught compared to 520 women who taught. A\&M 842, "West Virginia School and Agricultural Statistics," WVU.
} 
Virginia Education Journal, commentators continued to advocate a traditional role for women throughout this period. Many West Virginia administrators retained this traditional mindset throughout the remainder of the nineteenth century. In an 1888 issue of The West Virginia School Journal, for example, one author suggested, "many (especially female) teachers do not 'magnify their office." He further explained that many female teachers were "even a little ashamed of their work. ${ }^{41}$ It is no wonder that by 1890 , only 2,058 women compared to 3,483 men taught in the public schools. In contrast, Pennsylvania's female teachers outnumbered men by two to one. $^{42}$

Administrators' reaction to female teachers directly impacted the way that leaders discussed women's education at the time, and as a result, many did not oppose it to the degree that they had prior to the War. The debate about female teachers that occurred after the Civil War informed administrators' similar debate about female students, and as a result, many local educators in the second half of the nineteenth century saw education and motherhood as two important aspects of womanhood. Furthermore, they recognized that countrywomen needed an education to be effective farm wives who contributed to the overall efficiency and success of the farm. Over time, they broadened the roles for women and began to include practical education. ${ }^{43}$ Administrators were also influenced by a national debate about female education. Prior to the 1870s, most opponents to female education argued that women simply could not be as smart as men. Women's education went against the social order, which most men considered

\footnotetext{
${ }^{41}$ Common School Education, untitled, The West Virginia School Journal 7, no. 6 (June 1888): 11.

${ }^{42}$ State Superintendent of Schools, The History of Education in West Virginia, revised ed. (Charleston: Tribune Printing Company, 1907), 8; D. J. Waller, Report of the Superintendent of Public Instruction of the Commonwealth of Pennsylvania For the Year Ending June 2, 1890 (Harrisburg: Edwin K. Meyers, 1890), vii. In Pennsylvania, 16,111 women compared to 8,382 men taught.

${ }^{43}$ The West Virginia School Journal, volumes 1-25.
} 
biologically determined. ${ }^{44}$ Edward H. Clarke, a professor at Harvard Medical School, for instance, lead a national debate on the impact of education on women's health. ${ }^{45}$ The Pennsylvania School Journal reacted to Clarke's presentation at the National Teachers'

Association meeting with some concern because, "the work assigned the female should not be greater than her constitution can properly sustain.” The Journal concluded, however, that "when co-education is properly conducted, the difference of sex is not a source of very much difficulty... ${ }^{, 46}$ Pennsylvania educators thus acknowledged his ideas while at the same time suggested that women could sit next to boys in the same classroom and complete the same work. Unlike Clarke, rural administrators argued that women needed the same, basic education, and most assumed that it would be used when they became mothers. They recognized that more women continued to enter schools, and so rather than disapprove of their presence, male administrators encouraged women to gain the skills necessary for motherhood. ${ }^{47}$ Their stance resonated with "domestic" feminists, like Julia Ward Howe, who asserted that women deserved education to improve their skills as mothers. In her response to Clarke, Howe criticized his pseudoscience and called on society to accept widening gender roles. ${ }^{48}$ West Virginia school

\footnotetext{
${ }^{44}$ Biological determinism is the combined sociological theories that propose a person's or group's biology defines their personality and social behavior. Opponents to the concept, particularly feminists, see gender as entirely socially constructed. Biology determines one's sex, which may be different than the gender they internalize and express. Race is also socially constructed to identify differences between hegemonic and subordinate groups. See Stephen Jay Gould, The Mismeasure of Man (New York: W.W. Norton \& Co., 1981); Anne Fausto-Sterling, Myths of Gender: Biological Theories About Women and Men (New York: Basic Books, 1985); Linda Nicholson "Interpreting Gender," Signs 20, no. 1 (Autumn, 1994): 79-105.

${ }^{45}$ Edward H. Clarke, Sex in Education; or A Fair Chance for Girls (Boston: Rand, Avery, \& Co., 1873); John L. Rury, Education and Women's Work, 23-26. According to Rury, Sex in Education was reprinted eleven times in six years and proved popular among administrators.

46 "National Teachers' Association: Recent Meeting at Detroit—Review of Proceedings—Topics of Discussion," Pennsylvania School Journal 23, no. 4 (October 1874): 140.

${ }^{47}$ James P. Wickersham, Report...For the Year Ending June 3, 1867, 317; W. R. White, Third Annual Report ...West Virginia, 18-25.

${ }^{48}$ Julia Ward Howe, Sex and Education: A Reply to Dr. E.H. Clarke's "Sex in Education," (Boston: Roberts Brothers, 1874); John L. Rury, Education and Women's Work, 29. John Rury argues that Howe (1819-1910) was a domestic feminist that did not try to change the sexual division labor. Instead, she "sought to redefine women's roles in a manner that permitted them to measure their own lives in terms of peculiarly female contributions to social development." Howe was a social and political activist during the nineteenth century and was better known for
} 
leaders agreed with Howe's argument and reprinted her article, "Defects in the Education of American Girls," in its school journal. In this article, Howe supported women's education, but only because it prepared women for motherhood. Accordingly, it was "necessary for the state, the church, and the family that women shall be thoroughly instructed in its rules as to be able not only to practice but also to teach them con amore. ${ }^{, 49}$ Howe's recommendations restricted female intellect to three domains: the home, church, and school. By reprinting this article, rural administrators demonstrated that they wanted to channel female opportunities to fulfill a traditional end.

Education leaders in West Virginia continued to reassert traditional gender norms throughout the nineteenth century. To most administrators, men were believed to hold intellect and discipline, while women held beauty and sentimentality. They asserted that even "ignorant people" could "snuff true manhood from afar," as if it wafted through the halls and lead to the classroom where men sat in the "presence of true merit." ${ }^{50}$ According to a male student at West Virginia University, erudite women came too close to manhood. No man would want her because "she never was constructed on the old domestic plan," and thus could not bring domestic skills into a marriage. ${ }^{51}$ Accordingly, if men lived to learn, then women lived to love, so much so that a woman who had an abusive husband should starve herself, "to pay his way out." And then

rewriting the words to "John Brown's Body" to create the "Battle Hymn of the Republic." The ideals espoused by Howe are also evident in popular magazines like Godey's Lady's Book and Harper's Bazaar, which told women to uphold their responsibilities as mothers first and wives second. Such publications encouraged women to learn primary education to inculcate their children but told them to also remain feminine, as shown by the plethora of articles about fashion, literature, and general frivolities.

49 Julia Ward Howe, "Defects in the Education of American Girls," The West Virginia School Journal 7, no. 12 (December, 1888): 4.

${ }^{50}$ L. W. Fire, “An Evil Weed,” The West Virginia School Journal 1, no. 8 (June 1882): 6.

51 "A New Fashioned Girl," The Daily Athenaeum 2, no. 5 (November 8, 1888): 15; Amy Dru Stanley's From Bondage to Contract: Wage Labor, and the Market in the Age of Slave Emancipation (New York: Cambridge University Press, 1998) argues that women after the Civil War demanded more autonomy in marriage because to them, wives felt bonded to their husbands as slaves bonded to masters. To her, women still subscribed to motherhood and domesticity but wanted self-ownership, especially since more women viewed marriage as a contract. 
for the sake of love, she should appeal to the judge "to "spare the man, just once more."

Besides exonerating domestic violence, this author places gender into two stark camps: to learn is masculine and to love is feminine. In West Virginia, men consistently pushed against any transformation of gender roles, and often asserted time-honored ideals of manhood.

Other West Virginia administrators held firm to traditional ideals of womanhood, even to the extent that they eroticized female students. The poem, "The Sweet Girl Graduate," published in The West Virginia School Journal, reinforced the feminine, erotic qualities of educated women in hopes of subjugating them. It does not advocate for women's education or their upward mobility, and goes beyond pigeonholing women strictly as child bearers. ${ }^{53}$

In snowy lace and satin, Bedecked with floral glory, She bows and reads, in Latin, The class salutatory.

A scarlet rose resembles

Her cheek aglow with blushes;

Her timid bosom trembles

Like singing hermit thrush's.

Her charming agitation, More than any word she utters, Captivates my admiration;

And my heart excited flutters.

$\mathrm{Oh}$, fair and gentle creature, Trained in language and belles lettres, I'm very sure no teacher Than I can love you better.

She has won my heart completely Spite of faults in Roman grammar, For she smiled so very sweetly Just because she chanced to stammer.

\footnotetext{
52 John M'Govern, "Bachelors," The Daily Athenaeum 1, no. 15 (May 1888): 175-175.

${ }^{53}$ W. H. Venable, "The Sweet Girl Graduate," The West Virginia School Journal 7, no. 6 (June 1888): 5.
} 
She's the flower of the college;

I care not, Sir Professor,

What you say about her knowledge,

She is educated, --bless her.

Though I never saw the maiden

Ere to-night, nor photo of her,

I shall go away, heart-laden,

Her devoted slave and lover.

Come hither, gracious usher!

Carry these enraptured roses,

And give them to you blusher,

When her salutation closes.

The poem's writer is more enchanted by the woman's physical reaction to reading than her mental one. She reads refined literature with a moral agenda, which was deemed more appropriate for a female audience, and Latin, the studied language of the elite. In response, the writer depicts the woman's intellect as useful only to the extent that it makes her more suitable for an elite marriage. Also, the writer draws attention to the stammer to imply that the female graduate cannot be nearly as confident and successful in her studies as a male pupil. The author trivializes female intellect and molds his subject to the gendered expectations of these male school leaders. ${ }^{54}$

As the century progressed, more West Virginia administrators began to accept rural women's education. A decade after the Journal published Venable's poem, local education leaders, like Waitman Barbe, publicized his support for female education. Barbe was editor of The West Virginia School Journal and faculty member of the English department at West Virginia University. In one of his short stories, entitled "Martha," the narrator recounts the tale of a "poor mountain girl" who lived only for necessity, or "the word that is written on every page of

\footnotetext{
${ }^{54}$ W. H. Venable, "The Sweet Girl Graduate," 5; Allyson Perry, "The Gendered Profession: West Virginia Administrators React to Women in Education, 1863-1917," Graduate History Review 4, no. 1 (Fall 2012): 38.
} 
the life of the hills." Accordingly, education often came second to work. One day, however, an old man who had devoted "his life to what he called a ministry of education," gave her a few books, including an old speller and reader. Martha read them with such passion, but as she grew older, she shed many of her childhood interests and fell in love. When she and her family prepared for the wedding, "Martha set to work at once to fit herself for the new sphere in which she was to live. She borrowed books as the neighborhood afforded and read them with loving eagerness. ${ }^{, 55}$ For Barbe, educated women continued their learning even after they fell in love and married because education was a lifetime endeavor that should never stop for rural women.

As the century progressed, West Virginia administrators became increasingly comfortable with the growing number of women. In The West Virginia School Journal, a staff writer noted the national climate for this "feminization., ${ }^{, 56} \mathrm{He}$ entitled his piece, "School Boys Sissified," and pointed out that many national reformers felt that "there are too many women teachers in the schools and that the boys are being "effeminized." ${ }^{57} \mathrm{He}$, however, rejected that notion. Instead, the staff writer asserted that leaders should not be "alarmed" because "we doubt whether the number is large and whether it has been proven at all." Not only was "feminization" unfound, but also the "nature of American masculinity" "will bear a little toning down from its

\footnotetext{
${ }^{55}$ Waitman Barbe, "Martha," manuscript in Box 1, A\&M 831, "Waitman Barbe Collection,” WVU. Published later as In the Virginias, Stories and Sketches (Akron, Ohio: The Werner Company, 1896).

56 "Feminization" of schools was first defined in the article "The Feminization of Public School Teaching: Crosssectional Analysis, 1850-1880," by Myra H. Strober and Audri Gordon Lanford in Signs 11, no. 2 (January 1986), 212-235. During this time period, teaching became a female profession and resulted in gender stereotypes and wage disparity. John L. Rury in Education and Women's Work argues further that the feminization of the high school occurred in both rural and urban schools and became a great issue in the late nineteenth century (17). Perlmann and Margo in Women's Work? provide another chapter on feminization and suggest that urban graded schools stimulated feminization but that feminization also occurred in rural areas.

${ }^{57}$ Staff writer, "School Boys Sissified," The West Virginia School Journal 22, no. 5 (September-October, 1908): 21.
} 
roughness and strenuousness." In fact, female teachers and mothers could provide this "need of gentleness and refinement," and were deemed vital to shaping American manhood. ${ }^{58}$

This gradual acceptance of female education in West Virginia drew upon models in neighboring states. Many leaders used surrounding states, like Pennsylvania, as a measuring stick. For example, Waitman Barbe also wrote a telling — albeit embellished—-tale of Monongalia County, West Virginia, Superintendent Alexander Wade. Barbe explained that one day, Wade went around to the country schools and found that children brought whatever books they liked and the teachers made no attempt to standardize the curriculum. When he came home "thoroughly discouraged," "he saw a high school diploma (from another state) hanging on the wall of the room where he was spending the night. Mr. Wade stood before it and pondered." The next day, he went into the first rural school he saw and asked for their cooperation in implementing a new curriculum. That same year, he requested a compulsory law to improve attendance. He also instituted eighth grade graduations to bolster community support of the free schools. ${ }^{59}$ According to Barbe, who wrote forty years later, "That was the beginning-there in a little country school house in Monongalia county — of the whole system of graduation in country schools as it now exists in one form or another throughout the whole country." $" 60$ Throughout the state, most rural communities responded well to the new system set up by Alexander Wade, and families started sending more of their children to school. Also, the length of the school term increased from 59.4 average days a year in 1865 to 105.6 average days in $1890 .^{61}$

\footnotetext{
${ }^{58}$ Staff writer, "School Boys Sissified," 21; John L. Rury in Education and Women's Work also describes this as administrators' fear of feminization (67-70). See also Gail Bederman, Manliness and Civilization: A Cultural History of Gender and Race in the United States, 1880-1917 (Chicago; The University of Chicago Press, 1995).

${ }^{59}$ A.L. Wade, County Superintendent, Catalogue of the Free Schools of Monongalia County, West Virginia, $1875-$ 1876 (Morgantown: Morgan and Hoffman, 1876), 5 in A\&M 462, "Monongalia County Schools Catalogue," WVU.

${ }^{60}$ Waitman Barbe, “A Bit of Educational History," The West Virginia School Journal 37, no. 3 (May 1908): 18.

${ }^{61}$ State Superintendent of Schools, The History of Education in West Virginia, 8, and 25-30.
} 
These models of modern education shaped attitudes toward female schooling. William P. Willey, a law professor at the all-male West Virginia University, argued that "West Virginia's Wrong to Womankind" was that it did not provide higher education for women. ${ }^{62}$ Looking at more innovative states, he realized "that if a West Virginia girl wants more than a primary school education, she has to go out of the State to get it." Willey equated modernity with higher education for women, but his advocacy was radical for most of West Virginia during this time. ${ }^{63}$ In 1885, the West Virginia House of Delegates blocked an act that would have established coeducation at West Virginia University, despite top administrators backing the law. The West Virginia Senate stopped a similar bill as well, and it took four more years for West Virginia University to admit women. Willey's encouragement depicts a new wave of thinking for the modernizing state, but only some administrators agreed with Willey's sentiments. ${ }^{64}$

Changing models of marriage also influenced educators. Some now saw women as complements to men. One commentator described marriages filled with "generous allowances of mutual freedom." ${ }^{65}$ This new form of marriage was "emblematic of the union of mind to mind and heart to heart. ${ }^{, 66}$ Men were supposed to appreciate the wisdom and love a woman could bring to a marriage. Women, however, still had to retain their womanhood — coded as beauty,

\footnotetext{
${ }^{62}$ Benj. S. Morgan, ed., The West Virginia School Journal 7, no. 6 (June 1888): 1.; W. P. Willey, "West Virginia's Wrong to Womankind," The West Virginia School Journal 7, no. 6 (June 1888): 6-7. For more information on William P. Willey, see the introduction to his An Inside View of the Formation of the State of West Virginia (Wheeling: The News Publishing Company, 1901), 1-4. His father, Waitman T. Willey was one of the first U.S. Senators from the state of West Virginia. Ancestry.com. West Virginia, Deaths Index, 1853-1973 [database on-line]. Provo, UT, USA: Ancestry.com Operations, Inc., 2011. Original data: "West Virginia Deaths, 1853-1970." Index. FamilySearch, Salt Lake City, Utah. From originals housed in county courthouses throughout West Virginia. "Death Records."

${ }^{63}$ Willey, "West Virginia's Wrong to Womankind," 7.

${ }^{64}$ The West Virginia School Journal 4, no. 2 (February, 1885): 4; Editorial, The West Virginia School Journal 7, no. 6 (June 1888): 1; Lillian J. Waugh and Judith G. Stitzel, “'Anything But Cordial': Coeducation and West Virginia University's Early Women," West Virginia History 49 (1990): 69-80; Ruth Babb Vossler, "Women and Education in West Virginia, 1810-1909," West Virginia History 36 (July 1975): 271-290.

65 "Husband and Wife." The Daily Athenaeum 1, no. 8 (February 9, 1888): 90.

66 "A Gentleman" and "Matrimony," The Daily Athenaeum 1, no. 7 (January 26, 1888): 74; Dr. Edward Brooks, "Be Women," The Daily Athenaeum 1, no. 7 (January 26, 1888): 81.
} 
domesticity, and skill—not bookish knowledge. She was expected to have unique personality traits, including "gentleness, purity, sincerity, scrupulous truth, and meek and patient forbearance and an invariable tone and manner of deference." ${ }^{67}$ Accordingly, men and women in West Virginia were by no means equal but rather distinctive components of a patriarchal household. Administrators in Pennsylvania more often accepted women's changing role in society. Louise G. Wilder, in her article "Educating Our Daughters" for The Pennsylvania School Journal, assured farmwomen that they could cultivate a "good air" as educated mothers. Traditionally, women went to fancy academies to be "capital housekeepers, devoted wives and mothers, and efficient philanthropists." The modern woman, however, has an "aim to acquire knowledge," usually through public schools. In her response to these new desires, Wilder asked, "Is there no way to secure both results?" For her, educated women should complement the traditional ideals of womanhood with modern aspirations. ${ }^{68}$

Some Pennsylvania authors also started to recognize a great disparity between rural men and women's education. The Juniata Sentinel and Republican of Juniata, Pennsylvania, noted, “The farmer's boy goes to college, finds cheap tuition, wins a scholarship perhaps, boards in commons, earns money during vacation, and gets through, while his sister stays at home." In calling attention to the women, the author drew the readers' awareness to inequities in coeducation. For many rural families, sons attended school more often and found a myriad of ways to pay for their education. Their daughters, on the other hand, had fewer options for advanced schooling and many had no way to pay for such opportunities. In order to enact

\footnotetext{
67 "Husband and Wife," 90.

${ }^{68}$ Louise G. Wilder, "Educating Our Daughters," The Pennsylvania School Journal 41, no. 10 (April 1893): $417-$ 419.
} 
change, the author called for "cheaper schools of an equal excellence," particularly for farming families that could not afford to pay for college. ${ }^{69}$

As more local leaders in Pennsylvania accepted the rise of female attendance and women's broadened educational interests, many began to reevaluate masculinity. After the Pennsylvania Agricultural College admitted women, one administrator claimed that "the male students have improved in deportment and dress, the meetings for literary and religious exercises have been more interesting and profitable, and especially the advantages offered by the institution have become available to citizens who are the parents of daughters as well as to those who are the parents of sons. ${ }^{, 70}$ Outside of the College, other local writers adapted their concept of heterosexual relationships as more women attended school and took advantage of new opportunities. An author in The Somerset Herald expressed apprehension about women who married early because "mental growth is suspended in the large majority of women." She further inverted the traditional notion of education as "a means toward an end," or women going to school to marry a distinguished man. To her, "all education from such a motive is a mistake to begin with," and instead recommended that her female readers take time to attend school and mature on their own before marriage. ${ }^{71}$ His author's attitude toward womanhood broadened to include education and ambition, not just domesticity and motherhood. ${ }^{72}$

\footnotetext{
69 “A Word for the Women," Scribner's Monthly, reprinted in Juniata Sentinel and Republican, October 13, 1875.

${ }^{70}$ James P. Wickersham, "Report of the President of the Agricultural College," in Report...For the Year Ending June 3, 1872, 274. Pennsylvania State University began in 1855 as the state's Farmers' High School. After Congress passed the Morrill Land-Grant Act, the state chose the high school as Pennsylvania's land-grant institution and renamed it the Agricultural College of Pennsylvania. The College admitted women in 1871, and joined the ranks of dozens of co-educational. land-grant institutions. The state finally changed its name to Pennsylvania State University in 1875 . Even the University of Texas, the University of Mississippi, and the University of Kentucky instituted co-education prior to West Virginia University.

71 "Early Marrying" The Somerset Herald, March 19, 1873.

${ }^{72}$ Gail Bederman in Manliness and Civilization argues that men in the late nineteenth century had to find innovative ways to justify masculine hegemony. Factors such as modernity, the New Woman, and the rising middle class threatened traditional concepts of masculinity. In rural West Virginia and Pennsylvania, male administrators also felt threatened by the influx of educated women, and so they reasserted their masculinity in various journals and school reports.
} 
Not all administrators in Pennsylvania accepted new notions of gender. In The Pennsylvania School Journal, Mary E. Wilkins described the beauty standard for schoolteachers in her article, "A Country Schooma'am." Wilkins admitted that she was "never extravagant in clothes..." and only wore avant-garde fashion occasionally. On an average day, "I was always sober and set-looking..." Right before she was set to marry one man, a new teacher named Maria Rogers came to help at her school. "She was good-looking, always smiling...Her hair curled, too." Rogers and the beau started to date behind Wilkins' back. For Wilkins, "I wouldn't believe it at first when folks came and told me he was going with her, and they thought I ought to know; but after a while I saw enough to satisfy me, myself.” Defeated, Wilkins wrote him a letter, giving them her blessing to marry, and later that spring, Rogers and the once contested man married. In this instance, the more beautiful and fashionable woman kept the man and the homely teacher stayed single. ${ }^{73}$

Still, by the tail end of the nineteenth century, more administrators from both states accepted the practical value of women's education. For example, James G. McSparren promoted the "Intellectual Development of Farmers Sons" in his essay published in the Pennsylvania State Board of Agriculture reports. He asserted that "the future well-being of our class, as well as of our government" depended upon the intellectual development of both farmers' sons as well as farmers' daughters. ${ }^{74}$ Because he and other like-minded reformers saw education as practical, more education and country life reformers turned their focus to rural schools. In 1900, the West Virginia legislature passed an act requiring public schools to teach elementary agriculture. The West Virginia School Journal then became the mouthpiece for this movement, by providing

\footnotetext{
${ }^{73}$ Mary E. Wilkins, “A Country Schoolma'am,” The Pennsylvania School Journal 44, no. 2 (August 1895): 59-60.

${ }^{74}$ James G. McSparren, "Intellectual Development of Farmers Sons," in Reports of the State Board of Agriculture (Harrisburg: Edwin K. Meyers, State Printer, 1890), 316.
} 
lessons to help teachers. ${ }^{75}$ Pennsylvania leaders also saw that "an effort has been made to keep some of the boys and girls on the farm at least," but they also recognized that with their modern, industrial economy, "We don't want them all on the farm for our future supply of professional and business men must as in the past come from the farm." In fact, they "believe more boys should remain on the farm, or become educated farmers than the present indicates."

At the same time, administrators realized that this practical education encouraged women to leave the farm. As a result, some grew anxious about this transition. According to M. B. Brosius, in his report to the Pennsylvania State Board of Agriculture, young women once "sought no better nor happier lot than her mother - to preside over a neat and well-managed farm-house." ${ }^{, 77}$ Others like Brosius equated sons' desire to leave the farm with daughters' desire for education. After going to school, he noted that women had an "inclination to leave the homestead and engage in school teaching, sewing or clerking in preference to the household vocations of a farmer's daughter., ${ }^{, 78}$ By the end of the nineteenth century, a number of young women on the farm increasingly sought an education, found training, and entered professions outside of the monotonous life on the farm. These changes extended into the early twentieth century, and an increased number of women sought similar professions, even if they were deemed female work.

More commentators echoed anxiety about the exodus of farmers' daughters. According to Dr. William S. Rolland for the Pennsylvania Agricultural Society, young women "engage in school teaching or sewing, or some other more exacting labor in preference to the household

\footnotetext{
${ }^{75}$ The West Virginia School Journal 19, nos 1-6.

${ }^{76}$ Nathan C. Schaeffer, Report of the Superintendent of Public Instruction of the Commonwealth of Pennsylvania, For the Year Ending July 6, 1914 (Harrisburg; William Stanley Ray, 1914), 40.

${ }^{77}$ M. G. Brosius, "Past, Present, and Future Condition of the Farmer," in Reports of the State Board of Agriculture (Harrisburg: Edwin K. Meyers, State Printer, 1890), 285.

${ }^{78}$ M. G. Brosius, "Past, Present, and Future Condition of the Farmer," 286.
} 
avocations of a farmer's wife and daughter., ${ }^{, 79}$ The author, however, suggested that if countrygirls and boys stayed on the farm, worked hard, and were patient for wealth, the next generation would surely yield the fruits of their labor. Rolland found that many young people left the farm because they sought "social and intellectual attainments" that were far-fetched. ${ }^{80}$ Instead, he recommended that the bemused farmers allow young men and women to try their hand at "city" professions, for "they will find that agricultural pursuits to be successfully conducted will fully employ the highest talents and the largest mental gifts. ${ }^{.81} \mathrm{He}$ ensured the farmers that their sons and daughters would soon tire of the professions and return to the farm, which Rolland regarded as the most cultivated profession. In reality, social and economic forces pulled a number of countrywomen from the farm, and they continued to leave during this time period. Rolland's anxiety embodies many rural leaders' fears of a new, rural life within a modernizing American society. ${ }^{82}$

When administrators heralded practical education for farmwomen, they signaled a broader idea of rural womanhood. Their notions of women's proper role in society shifted from moral and domestic to complementary and practical as time passed. Throughout the nineteenth and early twentieth century, however, administrators continued to use traditional notions of womanhood to regulate schools. From the top down, administrators published articles that called for a status quo, and they only began to adapt gender norms when it suited their needs.

\footnotetext{
${ }^{79}$ William S. Rolland, "Home Life on the Farm," in Agriculture of Pennsylvania Containing Reports of the State Board of Agriculture: The State Agricultural Society, The State Dairy-Men's Association, The State Horticultural Association, and the State College, For 1887 (Harrisburg: Edwin K. Meyers, 1888), 365.

${ }^{80}$ William S. Rolland, "Home Life on the Farm," 269.

${ }^{81}$ William S. Rolland, "Home Life on the Farm," 371.

${ }^{82}$ Hal S. Barron, "Teach No More His Neighbor: Localism and Rural Opposition to Educational Reform," in Mixed Harvest: The Second Great Transformation in the Rural North, 1870-1930 (Chapel Hill: The University of North Carolina Press, 1997), 43-80.
} 


\section{Chapter 4 \\ Farmgirls in the Classroom: The Influence of Public Education on Rural Society}

Maude Langdon was born in 1891 and grew up on a farm in Logan County, West

Virginia. As a young girl, she attended the local one-room schoolhouse in hopes of becoming a teacher. She continued her education in the rural schools, but she did not have the money to attend a high school far away from home. Instead, she paid for summer school, which trained her for the teachers' examination. She past the test, attained her certification, and began teaching in the country schools of her youth. She made an indelible impression on many of the "shoddy" youngsters, one of whom wrote a letter to Maude stating, "you taught us the real values of life and gave us encouragement, love, and understanding...you are my best remembered teacher."1 Several years later, Maude became the principal of a two-room school and saw a number of eighth grade graduates move on to high school. ${ }^{2}$

Maude's experience is indicative of the possibilities opened by the rise of public education during the late nineteenth and early twentieth century. During this time of broad societal transformation, women like Maude developed their own reasons to go to school and sought ways to satisfy their own interests, which varied for each woman. This chapter utilizes rural women's diaries, letters, articles, and oral histories to examine the ways in which countrywomen stretched or contested administrators' ideas about women's proper role to gain an education, develop personal goals, and place themselves at the center of rural society.

\section{$* * * * *$}

The first educational opportunities for nineteenth-century women were in elite academies or at home with basic instruction. At this time, learning was not for the masses, and the most

\footnotetext{
${ }^{1}$ Maude Langdon, interviewed by Marray Greenstein, April 20, 1974, transcript, p. 6, Marshall University Oral History of Appalachia, West Virginia and Regional History Collection, West Virginia University, Morgantown, WV [hereafter cited as WVU].

${ }^{2}$ Maude Langdon, interview, p. 1-13.
} 
affluent members of society sent their daughters to female academies. This private education provided cultured subjects, like history, writing, and mathematics, and prepared young ladies for marriage. They could also take "ornamental" electives, like vocal music or drawing, which were meant to refine and polish ladies looking for eligible suitors. Young women at the Washington Female Seminary in Washington, Pennsylvania, for example, could choose from a range of academic and sentimental courses. A few graduates found work at similar female academies or served as missionaries directly after school, but most married. ${ }^{3}$

While the middling and elite classes sent their daughters to private schools, farmgirls were often too far removed or too poor to attend school. ${ }^{4}$ As a result, they took advantage of home-based instruction within their own communities. Rural mothers often taught their own children simple arithmetic and reading. This education usually centered around farming chores, so that families maintained their homestead while teaching their children valuable and practical skills. Women also instructed neighboring children by gathering them in their homes for part of the day before sending children back to their families. ${ }^{5}$

Private academies produced some exceptional women who became models of female education. Emily Reed, for example, knew that from a young age she would attend school to

\footnotetext{
${ }^{3}$ Alumnae Association, Washington Seminary Alumnae Register, 1837-1924 (Washington: Observe Job Rooms, 1924): 14-38 in Folder "Washington Female Seminary 1837-1924," in the Washington Female Seminary Collection at Citizens Library, Washington, PA; Nancy Beadie, "Academy Students in Mid-Nineteenth Century: Social Geography, Demography, and the Culture of Academy Attendance," History of Education Society 41, no. 2 (Summer 2001): 251-262; Kim Tolley, "Science for Ladies, Classics for Gentlemen: A Comparative Analysis of Scientific Subjects in the Curricula of Boys' and Girls' Secondary Schools in the United States, 1794-1850," History of Education Quarterly 36, no. 2 (Summer 1996): 129-153; Lucia McMahon, "Of the Utmost Importance to Our Country": Women, Education, and Society, 1780-1820," Journal of the Early Republic 29, no. 3 (Fall 2009): 475-506; Ruth Coe Fisher, "A History of Women in Education in West Virginia," (Master's Thesis, Marshall College, 1947), 13-30.

${ }^{4}$ Mary Kelly in Learning to Stand and Speak: Women, Education, and Public Life in America's Republic (Chapel Hill: The University of North Carolina Press, 2006) examines women in the early Republic and antebellum America. She argues that women shaped their lives by finding an education. Private academies and seminaries promoted their interest, and many women found individual and social ways of gaining that education. See also: Wilma Dunaway, Women, Work, and Family in the Antebellum Mountain South (New York: Cambridge University Press, 2008), 115-120.

${ }^{5}$ Wilma Dunaway, Women, Work, and Family, 115-120.
} 
become a teacher. ${ }^{6}$ In 1858, she enrolled in the Morgantown Female Academy, located in Morgantown, Virginia, and immediately embraced her schoolwork. Writing to her mother, she explained that she felt "satisfied here... I have no desire at all to go home." She was excited to be at the academy and told her family and friends that she was committed to learning. Over the next several semesters, Emily continuously set goals for herself, and promised, "I am going to commence this session and see how much I can improve and how much I can study. O how I wish that I had improved the opportunities that I have had in my life to study..." Spending much of each day pored over her books, she explained to her mother, "it is nothing but hurry and confusion from Monday morning till Fryday night to get our lessons and recite them." Emily graduated a few years later, and through this training, she secured her dream job — teaching in Kanawha County, Virginia. ${ }^{8}$

Some of these early role models advocated for farmwomen's education. Lydia Jane Pierson moved to Liberty Township, Pennsylvania, after her wedding in 1821 . The area was a dense wilderness at the time, and her husband had to cut a new road to their land. After clearing the brush, they set up a makeshift cabin and went to work at cultivating their farm. While living in this isolated backcountry, Lydia began to write poetry and contributed to the Lycoming Gazette. She kept active in her writing and later became an editor for the Lancaster Intelligencer

\footnotetext{
${ }^{6}$ Emily Reed papers, Folder 2 "Reed Family Correspondence," Box 1 of 2, in A\&M 2876, "Putney-Reed Family Papers," WVU; Year: 1850; Census Place: Farmington, Van Buren, Iowa; Roll: M432_189; Page: 324B; Image: 165; Ancestry.com. 1850 United States Federal Census [database on-line]. Provo, UT, USA: Ancestry.com Operations, Inc., 2009; West Virginia, History of the Great Kanawha Valley, With Family History and Biographical Sketches, vol, 2 (Madison: Brant, Fuller \& Co., 1891), 102. She was born in Iowa, but her parents were originally from Charleston, Virginia. The Reeds kept in close contact with their family living back east, and they often discussed other family members who taught and loved to learn. Their communication also allowed Emily, her mother, and siblings to easily move back to Kanawha County, Virginia, after her father Samuel died in 1848 . During this time, her older brother, Robert, supported the family as a baker.

${ }^{7}$ Emily Reed to mother Maria D. Reed, November 16, 1858; Emily Reed to sister Mrs. Mary E. Putney, November 11, 1859; Emily Reed to mother Maria D. Reed, May 2, 1859; Emily Reed to mother Maria D. Reed, 1858 , Folder 2 "Reed Family Correspondence," Box 1 of 2, in A\&M 2876, "Putney-Reed Family Papers," WVU.

${ }^{8}$ Alumnae Association, Washington Seminary Alumnae Register.
} 
in Lancaster, Pennsylvania. ${ }^{9}$ Despite her involvement, she found that other farmwomen had few outlets to share their knowledge and interests. In 1851, she saw that The Pennsylvania Farm Journal published no articles pertaining to rural women in its first issue. She wrote to the editors, and asked, "Why is it that so little is said and done for the benefit of the farmer's wife..." In her experience, farmwomen took care of the small children and performed all of the work in the home without little rest or assistance. According to Lydia, these mothers could use an article or two written by the "wise women" "to aide each other in the management and education of our children and also to enlighten each other..." Taking her request to heart, the editors included a "Domestic Department" in the third issue and printed her letter. ${ }^{10}$

With subscription material, like The Pennsylvania Farm Journal, other farmwomen shared their interests and opinions. In September 1853, Julia D. from Westmoreland County accused the Journal of not supporting “women's rights” because it had no sentimental pieces or domestic-living articles. ${ }^{11}$ Upon reading this letter, Anna Brookfield from Delaware County responded, "I trust that the dish of sentiment and poetry, that you have cooked up for your fair correspondent of Westmoreland County, is intended for her alone." 12 Throughout the rest of her letter, she criticized both Westmoreland County and the Journal for thinking that all women were interested in sentimental writings rather than articles about agriculture. Concluding her letter, she asked, "What kind of mothers would such women make, for man, whose intellect is to control the destinies of the nation?"13

\footnotetext{
${ }^{9}$ Pennsylvania, History of Tioga County, Pennsylvania (Harrisburg: R.C. Brown, 1897), 249-258.

${ }^{10}$ S. S. Haldeman, ed., "Domestic Department," The Pennsylvania Farm Journal 1, no. 1 (June 1851): 85-86; Stevenson W. Fletcher, Pennsylvania Agriculture and Country Life, 1840-1940 (Harrisburg: Pennsylvania Historical and Museum Commission, 1955), 357. Joan Jensen further examines Pennsylvania farmwomen's work and lives in Loosening the Bonds: Mid-Atlantic Farm Women, 1750-1850 (New Haven: Yale University Press, 1986).

${ }^{11}$ Julia D., "Women's Rights," The Pennsylvania Farm Journal 3, no. 5 (August 1853): 139.

12 Anna Brookfield, “Women's Rights," The Pennsylvania Farm Journal 3, no. 6 (September 1853): 190.

${ }^{13}$ Brookfield, "Women's Rights," 190.
} 
Gradually, more farmgirls benefitted from the free, public schools as the common school movement gained popularity. The Pennsylvania legislature enacted common schools in 1834, and a number of rural families began sending their children to school. ${ }^{14}$ In the newly formed state of West Virginia, however, many country people did not accept the change at first. Some rural communities often waited years to enact free schools and found only a handful of literate children when sessions finally started. According to Levi Johnson, school superintendent of Barbour County, West Virginia, "One lady informed me, that twenty-five of her scholars, at the beginning of her school, were unable to repeat the alphabet!"15

Once they began public school, rural girls and boys shared the same curriculum and teacher. The standard curriculum varied by grade and level, but it generally included grammar, reading, writing, penmanship, history, geography, arithmetic, and algebra. ${ }^{16}$ Many students also had female teachers, who initially worked in the summer term to free male teachers during the busy harvest season. Over time, more Appalachian women taught in the public schools, and by 1860, women became the majority of the teaching force in Pennsylvania. Women in West Virginia, however, did not make up the majority of teachers until the twentieth century. ${ }^{17}$

As farmchildren saw more of their friends attend public schools, those who could not found creative ways to learn. In a short story printed in The Lewisburg Chronicle, two young sisters named Mary and Nelly had a difficult time attending school. With some embarrassment,

\footnotetext{
${ }^{14}$ James P. Wickersham, Report of the Superintendent of Common Schools of the Commonwealth of Pennsylvania, For the Year Ending June 4, 1866 (Harrisburg: Singerly \& Myers, 1867), 317.

${ }^{15}$ W. R. White, Second Annual Report of the State Superintendent of Free Schools, of the State of West Virginia (Wheeling: John Frew, 1866), 19. The author italicized the words in the original document.

${ }^{16}$ A\&M 462, "Monongalia County Schools Catalogue," WVU; W. R. White, Second Annual Report ...of West Virginia, 36; Juniata District Schools Monthly Reports, 1887-1896 (Harrisburg: Lane S. Hart, 1877) in School Records, Box 3 and Union School, Henderson District Schools Monthly Reports, 1887-1896 (Harrisburg: Lane S. Hart, 1877) in School Records, Box 3 at the Huntingdon County Historical Society Archives, Huntingdon, PA.

${ }^{17}$ Joel Perlmann and Robert A. Margo in Women's Work?: American Schoolteachers, 1650-1920 (Chicago: The University of Chicago Press, 2001) examine the hiring practices and school terms in various states. They conclude that fewer teachers were female in the South, and women taught summer sessions for younger children and girls to free up young boys for farm work.
} 
Mary told her schoolteacher that her widowed mother "can not spare both of us conveniently, and so we are going to take turns, I'm going to school one day and sister the next." At night, Mary taught her sister Nelly what she had learned in school, and then the next day Nelly went to school and then later that night, taught Mary what she had learned during the day. Both wanted "to study very much," so their mother sent them to school the only way that she knew how. By the end of the story, the teacher had noticed that Nelly did not want to play for fear that she would tear her dress. Upon further inspection, the teacher realized that Nelly wore the same clothes as her sister. Because she herself had a small income, the teacher spent the next summer saving enough money to buy Nelly her own calico dress. This gift meant a great deal to the sisters, who could finally attend class together. ${ }^{18}$

In the second half of the nineteenth century, free, public schools expanded farmgirls' opportunities, and they often developed their own ideas about female education. According to one former schoolgirl, "more girls finished school...They were inclined to care too much whether or not they had an education." ${ }^{\prime 19}$ Echoing this sentiment, Lucy Bayard Keyes explained that education "is a ladder by which we are mounting step by step." Lucy grew up in Green County, Pennsylvania, and wanted to take advantage of this "ladder" by attending school. In one of her school reports entitled, "Institutes," she praised the improving school system, which she believed provided her with life-long learning and prepared her to wear a "bright crown in the afterlife." At the same time, she knew that her educational journey would be filled with

\footnotetext{
18 "The Little Sisters," The Lewisburg Chronicle, February 16, 1855; Wilma Dunaway, Women, Work, and Family, 248; Wickersham, Report...Ending June 4, 1866, 317.

${ }^{19}$ Mr. and Mrs. Fred Vinson, interviewed by Stella Ray, transcript, p. 14, Marshall University Oral History of Appalachia, WVU.
} 
tribulations, but "if we toil on diligently, they will gradually disappear as mist before sunshine. $" 20$

When rural girls attended free, public schools, many found that they had an escape from the drudgery of farm life. A number of farmgirls who attended one-room schoolhouses recalled that their parents needed their help on the farm as much as they needed assistance from the boys. From a young age, farm girls learned to clean, cook, milk cows, and help with the planting and harvesting, among sundry other chores. ${ }^{21}$ When they came to school, however, girls were surprised at the freedom to have fun and do as they please. As Hazel Casteel of Clinton, West Virginia, remembered, "Recess and the playground held enchantment for me. I suppose it was because, coming from a large dairy farm, I had chores before and after school—all work and no play." 22 Florence Godrey of Monongalia County, West Virginia, also took full advantage of the time away from home. She "had no desire to be out of school. That's where the action was! Outside of school there was, of course, idle play, but that could be lonely because everybody else was in school."23

Free time and recess provided opportunities to have fun and play games. Often on pleasant days, teachers escorted students outside and supervised their play activities, such as baseball, tag, ring around the rosie, and hide and go seek. During the winter, teachers sometimes

\footnotetext{
${ }^{20}$ Lucy Bayard Keyes, "Institutes," circa 1883, in A\&M 2864, "Lucy Bayard Keyes Papers," WVU.

${ }^{21}$ Jo Hays, interview with himself, C.O. Williams, and Kathrine Houser Clouser, April 16, 1975, transcript, AX/CATO/PSUA/MS00083 State College Oral History Transcripts, 1970 Local Oral History Project, Paterno Library, Pennsylvania State University, State College, PA [hereafter cited as PSU]; Gertrude Humphreys, interview by Margaret Mary Lewis, April 22, 1982, Voices of American Homemakers, Eleanor Arnold Editor and Project Director, Paterno Library, PSU; Wilma A. Dunaway, Women, Work, and Family, 131-195; Shirley C. Eagan, “'Women's Work, Never Done': West Virginia Farm Women, 1880s-1920s," West Virginia History 49 (1990): 2136.

${ }^{22}$ Hazel Harner Casteel, "One-Room Schools Were More than 3-R Learning," in Folder 4, Box 1 in A\&M 2744, "Monongalia County Schools, Reminiscences," WVU.

${ }^{23}$ Florence L. Godrey, oral history, Folder 7, Box 1 in A\&M 2744, “Monongalia County Schools, Reminiscences," WVU.
} 
allowed students to sled, or they kept students inside for singing lessons or spelling bees. ${ }^{24}$ Florence Godrey also remembered that, although she loved recess, she was a skinny and sickly child who was often teased on the playground. Years later, she recalled that she "was afraid of the big boys. Perhaps this was justified for they did not hesitate to tease the younger ones." When she was just eight or nine years old, a group of boys pursued her and dared one of the boys to kiss her. She recalled "running, but they caught me and bumped me against the corner of the building. I still have a scar under my chin where I was cut and bleeding.",25

Because farmgirls had more time away from home, many also took advantage of the friendships formed at school. Most came from similar backgrounds, and in later recollections, women remembered that they, and most of their peers, owned no more than three dresses growing up. At the Cassville School in near Morgantown, West Virginia, Rose Core found that farmgirls easily formed "lasting friendships, learned to follow instructions, to cooperate and a most important part of education-work for the good of all and have a strong bond of togetherness. ${ }^{26}$ One such farmgirl, Annie Brewer, often sought female companionship at school. During her first few weeks, she joined a missionary society and a month later became the secretary. Her diary recounts numerous meetings and events that provided further support for her own interests. $^{27}$

Friendships enabled schoolgirls to engage in high jinks and sometimes break classroom rules. Maria McLean Carson, who attended the Washington Female Seminary, recounted in a letter to fellow alumnae a certain memory from their youth. She explained that one morning after

\footnotetext{
${ }^{24}$ Opal A. Garrison, oral history in Folder 3, Box 1 in A\&M 2744, "Monongalia County Schools, Reminiscences," WVU.

${ }^{25}$ Florence L. Godrey, oral history; Hazel H. Casteel, Ernest J. Nesius, and Joseph L. Flasching, One-Room Schools in Monongalia County, West Virginia (Morgantown: Monongalia Historical Society, 1997), 1-7.

${ }^{26}$ Rose Core Parker Cole, oral history, "Cassville School, As I knew It (1904-1913)" in Folder 2, Box 1 in A\&M 2744, "Monongalia County Schools, Reminiscences," WVU.

${ }^{27}$ Annie Brewer, diary, in A\&M 3187, "Robert E. Lee Keadle, Monroe County Diary,” WVU.
} 
roll call, she noticed her friends Mary and Jennie hiding a tiny black kitten as they sat in front of her. They were "holding the poor little wiggly creature behind their backs as we rose for prayer in the morning devotions." To her, it was "one of those funny memories that stick." ${ }^{28}$ Girls at one-room schoolhouses broke rules in a comparable fashion. Rose Core recalled that a group of girls during recess hid behind the schoolhouse to smoke cigarettes. This same group took younger girls "to the outside 'John' and told them the 'facts of life' and dirty stories." ${ }^{29}$ Difficult girls were not an anomaly. A male teacher in Monongalia County, West Virginia, explained that one day at recess, he and the students were playing, when suddenly, "the older girls went inside the building and locked the younger children and me outside. After talking with them for a while they decided to open the door and let us in." At the time, he was not sure of their motive, but years later asked, "Were they teenagers who were angry and aggravated with me? Or just two girls who had a crush on their teacher who was not much older than they?"30

Despite the camaraderie, schoolgirls did not always form lasting friendships. Bertha Filson recounted the story of a "peculiar" girl at Marshall University, who "was a brilliant girl, but she was sort of a masculine creature." She had no true home because her parents were divorced, so when she came to Marshall, she had a hard time making friends. One day, she and a group of girls sat on the front porch after dinner, when, "All of a sudden, someone let out a scream, and we all looked and there was a snake comin'." The peculiar girl "went down there and got a stick from one of the trees... and she beat that snake and killed it." She moved further

\footnotetext{
${ }^{28}$ Maria McLean Carson letter, May 30, 1950, in Folder “Alumnae Correspondence,” Washington Female Seminary Collection, Citizens' Library, Washington, PA.

${ }^{29}$ Rose Core Parker Cole, "Cassville School, As I Knew It (1904-13)."

${ }^{30}$ Unnamed male teacher, "One Room Schools," in Folder 3, “Clay Districts, 1921-1982," in Box 1, A\&M 2744, "Monongalia County Schools, 1840-1966," WVU.
} 
into the grass and found a whole nest of snakes. When she had finished with them, the "girl killed four or five snakes or maybe more and had 'em all piled up in the middle of the walk."31

As rural women relished in new friendships and time away from home, they found that free, public education also helped them to develop a sense a self. Many attended debates, volunteered with organizations, and reserved time for personal activities. Reading was an especially popular activity, and several women remembered that they read books whenever they had a free moment. Grace Sunbeam Ellis, who later became a teacher, explained that her lifelong "pastime was reading." During her teenage years, she especially liked when potential beaus bought her books. ${ }^{32}$ While many farmgirls enjoyed reading, others also found that they could improve upon their learning and achieve awards for their abilities. In fact, a number of schoolgirls became eighth grade valedictorians and received numerous accolades for spelling bees and competitions. ${ }^{33}$ In one such school contest, Galia Null of Greensburg, Pennsylvania, wrote in her diary that her friend "Katharine Kunkle got first prize but as she does not except prizes, she did not take it. Madeline Kline then got it. Elizabeth Lond and I were a tie for $2^{\text {nd }}, 334$

With a practical and basic education, many young women felt prepared for their traditional role as wives and mothers. In fact, the majority of rural schoolgirls ultimately married. To one student who attended a one-room schoolhouse, "As long as most Americans lived in rural areas and engaged in farming, the one-room school did educate the youth for this life style. Your father taught you how to farm and your mother taught you how to cook, mend and raise

\footnotetext{
${ }^{31}$ Bertha Filson, interviewed by Michael Galgano, January 31, 1974, transcript, p. 1, Marshall University Oral History of Appalachia, WVU.

${ }^{32}$ Grace Sunbeam Ellis, interview by Linda May, June 19, 1974, transcript, p. 4, Marshall University Oral History of Appalachia, WVU.

${ }^{33}$ Rose Core Parker Cole, "Cassville School, As I Knew It (1904-13)."

${ }^{34}$ Galia Null's diary, Carton 2, in the Null Collection \#108, Greensburg County Historical Society, Greensburg, PA [hereafter cited as GCHS].
} 
children—so off you went to school to get a bit of book learning. ${ }^{, 35}$ At public school, young girls learned basic subjects and were expected to have the same responsibilities as boys, such as fetching water for the class, hauling wood for the stove, and building a fire to warm the classroom. These young women were then prepared to take this knowledge back into the home when they married.

After bearing children, farmwomen were then able to apply this knowledge that they gained at school. As mothers, women exerted a significant influence on their children's learning. From a child's birth to about the age of five, farmwomen — outside of any other family member — spent the most time caring for, raising, and teaching these young children. Even after they started school, youngsters continued to learn practices and procedures from their mothers. ${ }^{36}$ For example, Rose Core of Cassville, West Virginia, heard stories from her mother who had once taught in a one-room schoolhouse. She told Rose that she had begun teaching when she was sixteen, and "did such a good job that she had no difficulty in getting a job after that." Rose's mother, however, eventually married, left the profession, gave birth to Rose, and spent the rest of her life caring for her family. Rose eventually graduated and began teaching in the rural schools during the twentieth century. ${ }^{37}$

At the same time, schools provided young women with additional skills when they needed to take on masculine roles on the farm. Because countrywomen often shared tasks with men and reciprocated work especially during critical harvest time, some labored beside their

\footnotetext{
${ }^{35}$ Ernie B. McCue, oral history in Folder 8, Box 1 in A\&M 2744, "Monongalia County Schools, Reminiscences," WVU.

${ }^{36}$ State Superintendent of Schools, The History of Education in West Virginia, revised ed. (Charleston: Tribune Printing Company, 1907), 52.

${ }^{37}$ Rose Core Parker Cole, “Cassville School, As I Knew It (1904-13);” Year: 1930; Census Place: Cass, Monongalia, West Virginia; Roll: 2548; Page: 17A; Enumeration District: 3; Image: 95.0; FHL microfilm: 2342282.
} 
husbands and fathers out of necessity and personal choice. ${ }^{38}$ This activity was not new for rural women, and according to the West Virginia Country Life Movement reports, many rural families came close to sharing the division of labor. Their reports also suggest that women and men had to work together for their personal benefit in addition to survival..$^{39}$ For this reason, public schools prepared farmgirls to accept additional chores during untimely events. If the male provider fell ill, died, or for whatever reason could no longer work, women had to take on the traditionally male farm work. ${ }^{40}$ For example, Fay Ball of Lincoln County, West Virginia, lost her father when she was six years old, and out of her twelve siblings, five were left to take care of the farm. Her mother "never said go to the fields, she said come to the fields and we all had to work and follow, and follow my mother because she was a real working woman." ${ }^{, 41}$

According to similar experiences, farmwomen had to take on leadership roles when parents died unexpectedly. Hettie Boland grew up on a farm in Summers County, West Virginia, and remembered her childhood vividly after her mother died in childbirth and her father died soon after from illness. Her parents left Hettie and her two sisters some money, so the girls raised their own food to survive. Hettie recalled that, "we didn't farm in a big way, we had our garden and our potatoes, our chickens, we, we raised hogs, had our own meat...” They also gathered "plenty of apples and plenty of peaches on the farm," but one day she and her sisters noticed that a group of men had stolen some of their peaches. This group had been making moonshine liquor and had stolen the girls' peaches to make peach brandy. Because the girls had no one else to

\footnotetext{
${ }^{38}$ Fay Ball, interviewed by Karen Handley, July 6, 1974, transcript, p. 10, Marshall University Oral History of Appalachia, WVU; Hettie Boland, interviewed by Vicky Elder, June 25, 1974, transcript, p. 4-20, Marshall University Oral History of Appalachia, WVU; Mr. and Mrs. J.C. Kessell, interviewed by Jeanann Leone, transcript, p. 3-5, Marshall University Oral History of Appalachia, WVU.

${ }^{39}$ Country Life Council completed questionnaire score sheets in Box 1, A\&M 3050, "West Virginia Country Life Movement, 1919-27," WVU.

${ }^{40} 1846$ diary in A\&M 2135, "Wilson-Lewis Family Papers," WVU, quoted in Wilma Dunaway, Women, Work, and Family, 143.

${ }^{41}$ Fay Ball, interview, p. 1.
} 
protect them, Hettie and her sisters knew that they had to scare them off. Hettie explained that the next time the group came down from the mountain to steal her peaches, she "got my pistol and I shot up through the orchard at um." Apparently, she did not harm any of the thieves, but one shot back with a shotgun. After that, though, the group did not return. ${ }^{42}$

While some rural women had to take on male farmwork out of necessity, others assumed traditionally male roles on their own accord. Annie Brewer, who devoted time to her missionary society, also took several days during the winter to hunt. In her personal diary, she listed how often she taught, aided her professors, and served as secretary for the society. Besides these activities, she also delineated the exact days that she hunted and the number of wildlife that she killed, often totally on her own. ${ }^{43}$

The preparation young women received in public schools also encouraged some to develop career goals. ${ }^{44}$ According to a former student of Galia Null, Miss Null wanted her female students to embrace new roles:

Often Miss Null predicts a great future for one of her studentsso (sic) she drills and lectures painstakingly with them. When the girl goes out to practice stenography, Miss Null fairly beams over the fact that the student is fulfilling her expectations. However, after the girl graduates and works a few months, the announcement of her marriage shatters the business position Miss Null had hoped for this excellent student. However, something like this does not discourage Miss Null for the next winter will find her working incessantly with a new find. ${ }^{45}$

\footnotetext{
${ }^{42}$ Hattie Boland, interview, p. 22; Lu Ann Jones explores farmwomen's work in the rural South in Mama Learned Us To Work: Farm Women in the New South (Chapel Hill: The University of North Carolina Press, 2002). According to Jones, women after the turn of the century still had a hard life, but they and their families were able to be self-sustaining (1-26 and 59-106). See also Melissa Walker's All We Knew Was to Farm: Rural Women in the Upcountry South, 1919-1941 (Baltimore: Johns Hopkins University Press, 2000) for a later, but relevant study of rural woman.

${ }^{43}$ Annie Brewer, diary, in A\&M 3187, "Robert E. Lee Keadle, Monroe County Diary,” WVU.

${ }^{44}$ Rose Core Parker Cole, "Cassville School, As I Knew It (1904-13);" Mary Crynock Sypolt, oral history, in Folder 4 “Clinton District, 1929-1982," Box 1, A\&M 2744, "Monongalia County Schools, 1840-1966," WVU.

${ }^{45}$ Emily Spino, "Efficient Hands," April 16, 1946 in Folder 7, "Galia Null Memorabilia," Box 1 in Null Collection \#108, GCHS.
} 
One such student, Rose G. Montel, utilized this training. Galia retained an undated letter from her, which explained, "this is my first dollar, and I feel as though it should go to you. I shall never be able to thank you enough, and you will never know how much I appreciate your getting the job for me." The dollar bill was no longer attached, but Galia kept the note amongst her other personal items, including diaries and scrapbooks. ${ }^{46}$

As schoolgirls broadened their career aspirations, they looked toward secondary and higher education to achieve their goals. Julia Tutwiler, an educator at Vassar College and active prison reformer, noticed this trend and recommended a plan for farmers' daughters to attend higher education. In her essay "A Self Support Problem," Tutwiler insisted that girls should not have to "assume the burden of self-support" during their high school or college years, even though many women had to and in fact were willing to take jobs despite mental and physical fatigue. $^{47}$ She used a fictional character, Katie, as an example:

Katie is a farmer's daughter. She has received all the elementary education, which the little country schoolhouse or the village academy can give her. She has a bright, eager intellect, whetted by the little it has received to an appetite for more. Her father has other children, and is one of the large class of worthy citizens who is just able to feed, clothe and physic his family and meet the necessary expenses of keeping up his farm or his business. ${ }^{48}$

Tutwiler then juxtaposed this situation with the education of Katie's brother Jack, who like many other young men in the late nineteenth century, went to work, saved money, and attended high

\footnotetext{
${ }^{46}$ Rose G. Montel to Galia Null, undated, in Folder 7, “Galia Null Memorabilia,” Box 1 in Null Collection \#108, GCHS.

${ }^{47}$ Julia Tutwiler (1841-1916) was born in Tuscaloosa, Alabama and was an advocate for educational and prison reform in America. She attended Vassar College and served as the president of Livingston State Normal School, later to become the University of West Alabama. See Julia S. Tutwiler, "A Self Support Problem," in The Congress of Women Held in the Woman's Building, World's Columbian Exposition, Chicago, U.S.A., ed. Mary Kavanaugh Oldham Eagle (Chicago: W.B. Conkey Company, 1894), 36.

48 Julia S. Tutwiler, “A Self Support Problem,” 36.
} 
school. According to Tutwiler, a girl like Katie had to work twice as hard in school and then support herself to be there in the first place. ${ }^{49}$

As schoolgirls' attendance increased gradually throughout the second half of the nineteenth century, rural education continued to influence farmwomen, their families, and the local community. After graduation, many farmwomen branched out into the community by organizing female circles. Some of these groups were informal, such as when women met to make apple butter or host a corn husking, bean stringing, or quilting bee. These venues gave women an opportunity to share interests, knowledge, and daily activities. In a more formal setting, some women attended new parents' associations and mothers' circles, where they discussed their children's education. ${ }^{50}$ To further involve progressive mothers, farmwomen's clubs sponsored by the Country Life Movement or the Agricultural Extension Service of West Virginia University recruited women "well informed on the home industries program." As the County Life Movement sought to bring progressive reforms to agriculture and rural society, the Agricultural Extension Services also hoped to bring technical training and agriculture education to rural people. West Virginia University had an active extension program and helped to organize scores of rural people for instruction. ${ }^{51}$ Wanting to take advantage of these opportunities, for example, a group of women in Kanawha County, West Virginia, requested that they form a female agriculture club. They planned to "get together and talk over their work and

\footnotetext{
${ }^{49}$ Ruth Coe Fisher, "A History of Women in Education in West Virginia," 31-62.

${ }^{50}$ Grace Sunbeam Ellis, interview, p. 7-8; National Congress of Mothers and Parent-Teacher Associations, "How to Organize Parents' Associations or Mothers' Circles in Public Schools with Suggestions for Programs" ed. $13^{\text {th }}$ (Washington, DC, 1914) in A\&M 1984, "Schools, Morgantown," WVU.

${ }^{51}$ Country Life Council completed questionnaire score sheets in Box 1, A\&M 3050, "West Virginia Country Life Movement, 1919-27," WVU; Wayne D. Rasmussen, Taking the University to the People: Seventy-Five Years of Cooperative Extension (Ames: Iowa State University Press, 1988), 90, 206.
} 
exchange ideas just as the girls do." For this reason, they saw these meetings as a "community gathering," which provided "a monthly lesson."52

In branching out into the community, farmwomen further advocated for young girl's cooperation in agriculture. Many farmwomen banded together to organize youth agricultural clubs and fundraise for their children's involvement. In these clubs, members received lessons in farming, horticulture, and agriculture as well as attended various farm shows to exhibit their own projects. Many took part in contests and competed for a trophy or cash prize. Through these activities, some believed, youth gained a sense of accomplishment and pride in farming. ${ }^{53}$ In addition to extracurricular activities, agricultural education became another project for farmwomen's groups. Countrywomen again joined together to see a change in the school curriculum. According to county agents' reports of the Agricultural Extension Service, "there is a general interest being awakened on the part of the teachers and of the parents in the club work in its relation to the schools." 54

Farmwomen did not only band together, but they also interacted with men to broaden their social capabilities. At school and community sponsored socials, girls and boys often intermingled and occasionally met future spouses. During box socials, for example, girls made their own dishes and lined them up on the table while boys walked around and sampled each. Most often, boys chose the dish of the girls that they liked most. Their interactions were not

\footnotetext{
${ }^{52}$ Miss Sutherland in Report of Agricultural Extension Work of the College of Agriculture, West Virginia University, 1913-14, p. 5, in A\&M 539, "West Virginia University, Agricultural Extension Service. County Agent's Reports," WVU.

${ }^{53}$ Report of Agricultural Extension Work of the College of Agriculture, West Virginia University, 1911-12 and 1912-13 in A\&M 539, "West Virginia University, Agricultural Extension Service. County Agent's Reports," WVU. ${ }^{54}$ Report of Agricultural Extension Work of the College of Agriculture, West Virginia University, 1913-14 in A\&M 539, "West Virginia University, Agricultural Extension Service. County Agent's Reports," WVU. Nancy Grey Osterud examines the bonds between rural women and their daily lives in Bonds of Community: The Lives of Farm Women in Nineteenth-Century New York (Ithaca: Cornell University Press, 1991) and Putting the Barn Before the House: Women and the Family Farming in Early Twentieth-Century New York (Ithaca: Cornell University Press, 2012).
} 
always positive, as some activities lent to competition, usually based on popularity or appearance, but the girls continued to socialize without parental control. ${ }^{55}$

Formal events, such as dances and weddings, also provided more opportunities for heterosexual interaction. Galia Null of Greensburg, Pennsylvania, used her diary to list and describe the numerous dances and weddings she attended, and in her scrapbook, she pasted dozens of calling and dance cards. According to this memorabilia, she and her sister Genevieve would go out often, and one night she had a "fine time at social. Bill brought me home." On April 3, 1911, she also "fooled around over town." ${ }^{, 56}$ Another female student, Helen Bottorf, of State College, Pennsylvania, remembered that the high school students attended a number of school functions, "but we weren't allowed to dance. Mr. Mairs, chairman of the School Board, and I forget who else, didn't approve of dancing." This rule, however, did not stop many of the young adults from interacting with one another and eventually dating. ${ }^{57}$

With more chances to socialize with men, some women broadened their ideas about social norms. For example, Lucy Clark of Mercer County, West Virginia, was fifteen years old when she began studying at Concord Normal School in 1884. She meticulously saved all of her beau's letters from this time in her life, and several of them were from a fellow student named John C. Meadows. He was twenty-two years old when they met at Concord Normal School and began to court. Initially, their relationship was romantic: afternoon calls, rendezvous on the campus grounds, and secrets about "being true to one's promise." Within a few weeks, however, Lucy told John that her father did not approve of him; he was a farmer, and John was a teacher.

\footnotetext{
${ }^{55}$ Georgia Gray Cook, oral history, in Folder 4 "Clinton District, 1929-1982," Mary K. Summers, oral history, in Folder 4 "Clinton District, 1929-1982," and P. Wayne Harner, oral history, in Folder 6 "Morgan District, ca. 19201985," in Box 1, A\&M 2744, “Monongalia County Schools, 1840-1966," WVU; Hettie Boland, interview, p. 4-20. ${ }^{56}$ Null Collection \#108, GCHS.

${ }^{57}$ Helen Bottorf, interview by Jo Hays and C.O. Williams, March 1875, transcript, AX/CATO/PSUA/MS00083 State College Oral History Transcripts, 1970 Local Oral History Project, Paterno Library, PSU.
} 
Not only was he in an increasingly female profession, but his family also had a reputation. She explained to John that they could no longer see one another. ${ }^{58}$ The freedom that schools provided, however, led Lucy to defy her parents. Lucy continued to see John, and they maintained their relationship by hiding their correspondence. When John sent letters, he signed his initials backwards and even went so far as to send letters through Lucy's friends or the postmaster in the next town. All the while, however, Lucy kept in contact with several other men, and some continued to write to her, even after they found out that she and John were together. At numerous points, John became jealous, once after hearing from other students that she was engaged to two men simultaneously. ${ }^{59}$ Ultimately they broke up, and John did not recover quickly. Friends of his wrote to Lucy, worried about his mental health. As for Lucy, she moved on to other men, taught for a year, and then married John C. Wise. She gave birth to three daughters and died in 1953 as a housewife. ${ }^{60}$

In similar fashion, other countrywomen contested their families' expectations when they snuck around to date. Bertha May Asbury lived in Sissonville, West Virginia, and during her teenage years, she had to "slip around" to court. As she later explained, Bertha would often lie to her parents and tell them that she was merely visiting her girlfriend. At her friend's house, Bertha

\footnotetext{
${ }^{58}$ Ancestry.com. West Virginia, Deaths Index, 1853-1973 [database on-line]. Provo, UT, USA: Ancestry.com Operations, Inc., 2011; Year: 1870; Census Place: Plymouth, Mercer, West Virginia; Roll: M593_1694; Page: 554B; Image: 183; Family History Library Film: 553193; Year: 1880; Census Place: Sherman, Boone, West Virginia; Roll: 1400; Family History Film: 1255400; Page: 366B; Enumeration District: 004; Year: 1880; Census Place: Jumping Branch, Mercer, West Virginia; Roll: 1408; Family History Film: 1255408; Page: 43D; Enumeration District: 082; John C. Meadows to Lucy Ann Clark, Jun 17, 1884; July 1, 1884; July 3, 1884; July 11, 1884; August 8, 1884; September 8, 1884; October 6, 1884; October 7, 1884; November 1, 1884; December 15, 1884; January 5, 1885; January 26, 1885; and July 13, 1885 in A\&M 2607, "Lucy Clark Wise Papers," WVU.

${ }^{59}$ John C. Meadows to Lucy Ann Wise, letter undated in A\&M 2607, "Lucy Clark Wise Papers," WVU.

${ }^{60}$ J.C. Shurnate to Lucy Ann Wise, September 1, 1884; J.C. Shurnate to Lucy Ann Wise, October 11, 1884; J.C. Shurnate to Lucy Ann Wise, December 19, 1884; W.B. Gaulin to Lucy Ann Wise, January 29, 1885; Joe Booker to Lucy Ann Wise, September 7, 1885 in A\&M 2607, "Lucy Clark Wise Papers," WVU; Ancestry.com. West Virginia, Marriages Index, 1785-1971 [database on-line]. Provo, UT, USA: Ancestry.com Operations, Inc., 2011; Ancestry.com. West Virginia, Deaths Index, 1853-1973 [database on-line]. Provo, UT, USA: Ancestry.com Operations, Inc., 2011; Year: 1920; Census Place: Athens, Mercer, West Virginia; Roll: T625_1962; Page: 5A; Enumeration District: 91; Image: 1104.
} 
would then meet her boyfriend, and they would spend private time together. Their ruse was so successful that Bertha's mother never discovered their meetings until after she and the beau had been together for three years. They ultimately dated for five years, and then married, moved to Charleston, West Virginia, and had two children. ${ }^{61}$

Despite the social mobility, opportunities for rural girls faced some limits, leading many ambitious farm girls to enter teacher preparation programs. According to J.C. Kessell of Given, West Virginia, "no higher education was available anywhere, this being strictly a rural county and there's no industrial work in the county, the ambition of every boy and girl was to become a school teacher." ${ }^{62}$ Maude Langdon of Logan County, West Virginia, echoed this sentiment. She believed that "girls at that time, they didn't go out of the state like they do now for jobs. They didn't think about anything like that." ${ }^{\text {}}$ "The majority of women who wanted to teach set aside money for their careers and attended the nearest high school, paid tuition, and boarded in the surrounding area. After graduating, they had to pass a teachers' examination before they began working. Even fewer farmwomen could afford courses at a private academy or a normal school, which offered specifically designed education programs. Regardless of which school they attended, women often took the same, practical courses as men and received the same preparation. $^{64}$

The majority of rural women who taught did so for only a short time before marrying. For those who planned to marry, teaching served as a steppingstone toward motherhood and a way to earn money before marriage. When female teachers did marry, many left the profession

\footnotetext{
${ }^{61}$ Bertha May Asbury, interviewed by Barbara Redman, March 5, 1973, transcript, p. 4, Marshall University Oral History of Appalachia, WVU.

${ }^{62}$ J.C. Kessell, interview, p. 3-5.

${ }^{63}$ Maude Langdon, interview, p. 11-12.

${ }^{64}$ John Rury, Education and Women's Work: Female Schooling and the Division of Labor in Urban America, 18701930 (Albany: State University of New York Press, 1991), 11-90; David Tyack and Elisabeth Hansot, Learning Together: A History of Coeducation in American Public Schools (New York: Russell Sage Foundation, 1992), 146165.
} 
in order to raise a family. According to Ethel Hunter, who grew up and taught in Point Marion, Pennsylvania, one of her female teachers eloped one weekend. Ethel remembered that she and her classmates left Friday after class, but on Monday, her teacher was not at school. Later, Ethel heard that the teacher and her fiancée ran away and married, and Ethel knew that, as a married woman, her teacher could no longer work in the public schools. ${ }^{65}$

\section{Others chose a career in education over marriage. Martha G. Rowe of Credo, West} Virginia, recalled that, "from the time that I can remember anything at all my one aim in life was to become a school teacher. They often kidded me that when I first began to talk I said that, 'I'm going to grow up and become a school teacher." ${ }^{, 66}$ She went to public school, received her teacher's certificate, and taught for a number of years. Later, she went back to school, earned a Master's degree, and served as principal. In total, she worked for forty-four years in the country schools of West Virginia. ${ }^{67}$ Ella Peach had a similar experience. She was born in 1853 to farming parents, who had recently moved to Uniontown, Pennsylvania, after selling the homestead. Although Peach never worked on the farm, she lived in a county dominated by agriculture. ${ }^{68}$ As a child and young woman, she attended private schools in Uniontown and began teaching at sixteen. She taught in the Uniontown public schools for her entire professional career and never married. ${ }^{69}$

\footnotetext{
${ }^{65}$ Ethel S. Hunter, oral history, in "Misc. Schools of Monongalia County" Folder, Box 1, A\&M 2744, "Monongalia County Schools, 1840-1966," WVU.

${ }^{66}$ Martha G. Rowe, interview transcript, p. 2, Marshall University Oral History of Appalachia, WVU.

${ }^{67}$ Martha G. Rowe, interview, p. 3-8.

${ }^{68}$ Year: 1850; Census Place: Union Township, Fayette County, Pennsylvania found in 1850 Census for Fayette County and "A FARM FOR SALE," Jan 10, 1850 in the Ella Peach folder, Fayette County Historical Society, Uniontown, PA; Pennsylvania, Agricultural Resources of Pennsylvania, c.1700-1960: Southwest Pennsylvania Diversified and Sheep Raising, c.1840-1960 (Harrisburg: Pennsylvania Historical and Museum Commission, 2009), 1-185. Fayette County and southwestern Pennsylvania was an area prime for sheep raising. Other families cultivated crops, such as corn, wheat, and oats. Peach was immersed in the rural lifestyle because "family and neighborhood labor predominated in this area" and would have been familiar with the seasonal planting times and daily duties of those on the farm.

${ }^{69}$ Obituary of Ella Peach, November 23, 1918, Ella Peach folder, Fayette County Historical Society, Uniontown, Pennsylvania.
} 
During the second half of the nineteenth century, more women entered the teaching ranks and by the twentieth century, they found their own niche in teaching. In Pennsylvania, women had become the majority of teachers by the Civil War, and by 1914, 31,246 women taught compared to 8,350 men. ${ }^{70}$ In West Virginia, women did not become the majority of teachers until 1904, when 3,877 women taught compared to 3,720 men. Ten years later, the gender gap increased to 5,640 female teachers to 4,180 male teachers. ${ }^{71}$

Some rural women also challenged administrators' authority when they lied about their marriages in order to retain teaching positions. Many of these women wanted a career and a relationship. In interviews years later, a number of female teachers described sneaking around to date, weekend elopements, and secret marriages in order to keep their jobs. ${ }^{72}$ Darlie Rumble Britton of Kincaid, West Virginia, did not tell friends or family about her marriage for over a year. She explained, "The main reason for the secrecy of our marriage was because of the fact that, at that time, the policy of the local Board of Education stated that a lady must stay out of the teaching profession for the first two years following her marriage.” After she and her husband went public about their relationship, the district placed Darlie on the substitute-teaching list for another year. ${ }^{73}$ Other couples who taught often avoided this standard by teaching in different areas or schools. For example, James and Ivy Summers of Walton, West Virginia, both started teaching in 1912 and had life-long careers in different school districts. ${ }^{74}$

\footnotetext{
${ }^{70}$ Nathan C. Schaeffer, Report of the Superintendent of Public Instruction of the Commonwealth of Pennsylvania for the Year Ending July 6, 1914 (Harrisburg: William Stanley Ray, 1914), 22a.

${ }^{71}$ M. P. Shawkey, Biennial Report of the State Superintendent of Free Schools of West Virginia for the Two Years Ending June 30, 1916 (Charleston: Tribune Printing Co, 1916),113.

${ }^{72}$ Donivon Edwin Adams, interviewed by Michael Galgano, September 19, 1974, transcript, p. 5, Marshall University Oral History Collection, WVU and Bertha May Asbury, interview, p. 1-4; Ethel S. Hunter, oral history.

${ }^{73}$ Darlie Rumble Britton, oral history, "My Life as a Teacher in Monongalia County Schools," in Folder 4, Box 1, A\&M 2744, "Monongalia County Schools, 1840-1966," WVU.

${ }^{74}$ James F. Summers and Ivy B. Summers, interviewed by Wilma Graham, November 4, 1975, transcript, p. 1-7, Marshall University Oral History of Appalachia, WVU.
} 
As teaching became a female profession, administrators reflected upon this changing role for women. Throughout the late nineteenth and early twentieth century, rural school administrators continued to discuss women's perceived natural ability to teach: "their moral and social natures are better adapted to the dispositions of children, they are naturally endowed with a much greater amount of patience and forbearance... her natural love of order; her love for the good, the beautiful, and the true, all eminently qualify her for this work." ${ }^{, 75}$ Besides suggesting that women had a natural ability to teach, administrators further reinforced the role of teaching as particularly feminine. In their various writings, many rural administrators referred to teachers with the pronoun "she." For instance, the article "In Which Rank Do You Stand?" asked teachers to place themselves in two categories — "The Good Teacher" and "The Poor Teacher." In each case, the author assumed the teacher to be female. ${ }^{76}$

At the same time, administrators continued to curtail female teachers' advancement by capping their salary and forcing them to be single. Women earned considerably less than men. By 1914, female teachers in Pennsylvania made on average $\$ 49.44$ a month compared to male teachers, who made an average of $\$ 68.06$ a month. ${ }^{77}$ Second, rural administrators expected them to remain single. Few districts had regulations or policies regarding married or pregnant teachers, but many retained the traditional custom of not hiring married women or mothers. According to these local leaders, a good female instructor taught for a while, and "Then 'she marries and lives

\footnotetext{
${ }^{75}$ James P. Wickersham, Report of the Superintendent of Common Schools of the Commonwealth of Pennsylvania, For the Year Ending June 3, 1872, (Harrisburg: B. Singerly, 1872), 100.

${ }^{76}$ Staff writer, “In Which Rank Do You Stand?" The West Virginia School Journal 15, no. 6 (June 1896): 575; Allyson Perry, "The Gendered Profession: West Virginia Administrators React to Women in Education, 18631917," Graduate History Review 4, no. 1 (Fall 2012): 40; John Rury describes the rise of feminization in schools in Education and Women's Work, 1-50.

${ }^{77}$ Nathan C. Schaeffer, Report...for the Year Ending July 6, 1914, 22a. West Virginia did not delineate between male and female teacher salaries in their reports in the twentieth century. See M.P. Shawkey, Biennial Report of the State Superintendent of Free Schools of West Virginia for the Two Years Ending June 30, 1914 (Charleston: Department of Free Schools, 1914).
} 
happily ever afterward." ${ }^{\prime 78}$ Few of these writers justified their reasons to remove married teachers, but their actions continued to keep countrywomen from advancing in the profession. ${ }^{79}$

Despite these drawbacks, administrators reflected a larger shift toward female educators as the norm and influenced the continuing debate about female education. Public opinion revealed that many rural people accepted women as teachers and would not stand to see them in any other career. When she and her sister were deciding whether to continue their education, Nancy McNeel remembered that her father told his girls, "You can be anything you want as long as you teach school." For her, "There wasn't much choice there.” This assumption, however, was harder for Nancy's sister, who was a talented musician and wanted to have a career in performance. Their father stepped in again, and told her sister, "All right, you go ahead and finish college and get your teacher's certificate, then you can go on to do whatever you want to." By the time Nancy's sister finished school, she "just went ahead and taught school, you didn't go any farther." $" 80$

The public reinforced this shift, which kept rural women in a standard role of teacher as nurturer. Growing up in Wyoming County, West Virginia, Gladyce Nunn recalled that she only had one male elementary teacher. Instead, male instructors taught strictly at the high school because a male elementary school teacher "was considered a sissy." Gladyce eventually attained her teachers' certificate and started working in the one-room schools. In her experience, male teachers were better suited for secondary education because "youngsters are at the age where they are going through maybe a physical or emotional change." In fact, "some of them and in cases like that male teachers can handle them better. Females might be a little more

\footnotetext{
${ }^{78}$ Staff writer, "In Which Rank Do You Stand?" 575.

${ }^{79}$ Robert J. O’Brien, "Persecution and Acceptance: The Strange History of Discrimination Against Married Women Teachers in West Virginia," West Virginia History 56 (1997): 56-75.

${ }^{80}$ Nancy McNeel Currence, interviewed by Becky Tokarcik, April 29, 1974, transcript, p. 6-7, Marshall University Oral History of Appalachia, WVU.
} 
understanding but then when they reach that age, they don't seem to think that women could handle them as well as a male could."

For women who did not want to teach, other, increasingly female careers were opening. Bessie Jane Reed, who worked at the high school library in Fairmont, West Virginia, went out of her way to encourage rural students' interest in learning. She did 'excellent work in awakening the West Virginians," and according to the editor and professor Waitman Barbe, she did a fine job in making a special library exhibit that called "the attention of the students to what West Virginia writers have done and are trying to do." ${ }^{\prime 2}$ In addition to education positions, a number also became nurses. ${ }^{83}$ For example, Lillie Adkins, of Lincoln County, West Virginia, had a sister who graduated from Athens Hospital in Ohio. According to Lillie, "She chose to be a nurse, and I told her that I wouldn't do that at all." 84

While not the norm, a few rural women found non-traditional careers outside of education. ${ }^{85}$ For example, Ida Blackburn became a teacher directly after graduating and then decided to change careers. Born in Donegal County, Pennsylvania, to farming parents, Ida attended a one-room schoolhouse and later attended the California State Teacher's College in Pennsylvania. After graduation, she taught for a short time, but she soon entered the Women's Medical College of Pennsylvania. According to The Daily Courier of Connellsville, Ida "was

\footnotetext{
${ }^{81}$ Gladyce K. Nunn, interviewed by Joe Woolwine, February 23,1974, transcript, p. 11-12, Marshall University Oral History of Appalachia, WVU.

${ }^{82}$ Mary Meek Atkinson to Bessie Jane Reed, August 14, 1923, and Waitman Barbe to Bessie Jane Reed, May 14, 1923 in A\&M 1845, "Bessie Jane Reed Collection," WVU.

${ }^{83}$ Maude Krumrine Hussey, interview by Jo Hays and C.O. Williams, July 30, 1976, transcript, AX/CATO/PSUA/MS00083 State College Oral History Transcripts, 1970, Local Oral History Project, Paterno Library, PSU; Celeste Brackett Newcomer, "One Week of Domestic Science at Storer," The Missionary Helper 36, no. 3 (March 1913): $72-76$ in Box 20, A\&M 2621, "Storer College;" Bertha Filson, interview; Huntingdon Public Schools, Rules, Regulations, and Course of Study, 36-43 in School Records, Box 3 at the Huntingdon County Historical Society Archives, Huntingdon, PA; John L. Rury, Education and Women's Work, 49-85.

${ }^{84}$ Lillie Adkins, interviewed by Mrs. Wilson, 1977, transcript, p. 17, Marshall University Oral History of Appalachia, WVU.

${ }^{85}$ Pauline McGraw Blatt, interviewed by Donna Musa, December 8, 1974, transcript, p. 6-7, Marshall University Oral History of Appalachia, WVU; John L. Rury, Education and Women's Work, 49-85.
} 
considerably older than her classmates," but she excelled and graduated a few years later. In 1896, she began her practice as the first female doctor in Greensburg, Pennsylvania. ${ }^{86}$

Because rural education provided farmwomen with more opportunities, some of these women broadened their expectations about heterosexual relationships. For some countrywomen, marriage was an avenue out of farming. Elwood Bausell's parents met at Russell College in Lebanon, Virginia. They eloped during college and eventually moved to Bristol, West Virginia, where Elwood's father worked as a publisher. ${ }^{87}$ In another instance, Hettie Boland knew that she did not miss the country life after she moved to Hinton, West Virginia. She had grown up on a farm in Summers County, West Virginia, where she attended to everyday household chores and went to the nearby one-room schoolhouse. She met her husband at a bean stringing and knew that he had worked in timber mills and the mines before marrying him. To Hettie, country life was "hard work and I'd rather live in town." $" 88$ Rather than continue a country lifestyle, Hettie married and moved to town with her husband, who worked in industry.

As rural women broadened their ideas about marriage, some sought out a spouse who encouraged their careers. According to Marion B. Vance and her husband Walter, each respected the other's personal choices and encouraged one another to attain their goals. Marion was in high school when she met Walter, who began teaching in her district and boarded with her uncle. Both came from farming families, and Walter continued to farm and work at a lumber mill during his early career as a teacher. After graduation, Marion started teaching in the country schools as

\footnotetext{
${ }^{86}$ Obituary of Ida Blackburn, The Daily Courier, Connellsville, Pennsylvania, February 22, 1935 and The Star (Reynoldsville, Pa.), November 11, 1908 at the Chestnut Ridge Historical Society, Jones Mills, Pennsylvania. ${ }^{87}$ Elwood Bausell, interviewed by Larry G. Mitchell, May 28, 1974, transcript, p. 1, The Appalachian Oral History Project of Alice Lloyd College, Appalachian State University, Emory and Henry College, and Lees Junior College, [hereafter cited as The Appalachian Oral History Project], WVU.

${ }^{88}$ Hettie Boland, transcript, p. 22. The changing notions of rural women's domesticity has been studied by Ann McCleary in her case study about women in Augusta County, Virginia. See: Ann McCleary, "Work in Progress: Domesticity and the Farm Woman: A Case Study of Women in Augusta County, Virginia, 1850-1940,"

Perspectives in Vernacular Architecture 1 (1982): 25-30.
} 
well, and when they married, she substitute taught and went to college every summer.

Eventually, Marion went back to teaching and worked full-time for several years. During her tenure, Walter taught, earned a Master's Degree in Education, and took post-Master's classes at Columbia University. ${ }^{89}$

While some women sought to leave the country, others brought these broadened expectations into their married life on the farm. According to the West Virginia Country Life Movement reports, a number of farming families found companionship at home and enjoyed a pleasant family life. ${ }^{90}$ In an interview years later, America Miller of Bandytown, West Virginia, explained that when she was growing up, her father was "just as much boss over us and the children as he was on his things outside." ${ }^{91}$ Shedding more light on this perception, Gladyce Nunn, explained that "Fathers used to be the lord and master, what he said was it but with modern ideas the parents have come to realize more that, uh, the mother is just as important in the home as far as making decisions as the father is." 92

As farmwomen's expectations for marriage broadened, their focus on personal education heightened. For some, learning was an antidote to monotony on the farm, and according to several oral histories, farmwomen took time out of their busy routines to enrich their minds, not necessarily to make the farm run efficiently. ${ }^{93}$ According to F. C. Atkinson, of Wayne County, West Virginia, his mother "read every book that came her way." At home, they kept lots of

\footnotetext{
${ }^{89}$ Marion and Walter Vance, interviewed by Michale J. Galgano, August 7, 1975, transcript, p. 8-72, Marshall University Oral History of Appalachia, WVU.

${ }^{90}$ Country Life Council completed questionnaire score sheets in Box 1, A\&M 3050, "West Virginia Country Life Movement, 1919-27," WVU.

${ }^{91}$ America Miller Jarrell, interviewed by Gary Miller, transcript, p. 14, Marshall University Oral History of Appalachia, WVU.

${ }^{92}$ Gladyce K. Nunn, interview, p. 14. See also Sally McMurry, Families and Farmhouses in Nineteenth-Century America: Vernacular Design and Social Change (New York: Oxford University Press, 1988), 177-208.

${ }^{93}$ Chambersburg Public Opinion, "The School and Farm," The Pennsylvania School Journal 31.9 (March 1883): 355.
} 


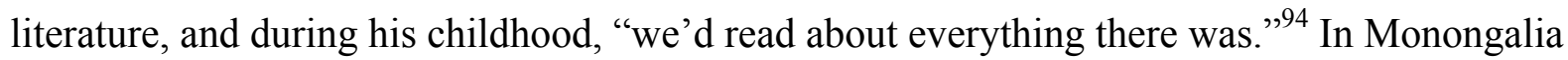
County, West Virginia, Florence Godrey also "had a good library at home which included school books used by my older brothers and sisters in other schools, as well as two or three excellent reference books - an encyclopedia, a large dictionary, the Lincoln Library, and others." In addition to literature, her "family subscribed to half a dozen magazines and newspapers." This focus on reading was important to her parents because they "did not have the opportunity for formal education much beyond grammar school, and they always encouraged their children to learn as much as they could: to read and to discuss school subjects and the current issues of the day." "95 This phenomenon was not unusual. According to the Agricultural Extension Service reports, many women read books, subscribed to magazines, and surveyed "local papers and farm papers. ${ }^{.96}$

Farmwomen's focus on personal education transferred to rural fathers, who began to help their girls study. In Florence Godrey's home, both parents helped with homework, especially her mother who "was vitally interested. She would read and discuss with her children the books that were brought home... She might help us to find a sentence or picture that was assigned from the daily papers." Her dad brought "home some practice sheets for arithmetic, and in the evening we would sit around the dinner table and do the exercises that were supposed to help us figure rapidly. ${ }^{, 97}$ In a similar experience, Ansel Peterson Hornor's father was a superior mathematician, and at night they would go through some of her problems for the next school day. When she woke up the following morning, Ansel would complete her chores while her father drilled her in

\footnotetext{
${ }^{94}$ F.C. Atkinson, interviewed by David Atkinson, December 9, 1973, transcript, p. 6, Marshall University Oral History of Appalachia, WVU.

${ }^{95}$ Florence Godrey, oral history.

${ }^{96}$ Abbott, WV report, p. 29 in Folder "Abbott, Upshur Co. in Box 1, A\&M 3050, "West Virginia Country Life Movement," WVU.

${ }^{97}$ Florence L. Godrey, oral history.
} 
mathematics. In an interview years later, Ansel acknowledged that she "had a great respect for my father" because he encouraged her education. ${ }^{98}$

By the twentieth century, rural parents believed that public education served either of two goals. One group of rural families realized that farming was not a viable option for all of their children, especially as agriculture began to decline in the late nineteenth century. As a result, they sent their children to school in hopes of preparing them for urban jobs and better opportunities. More young farmers in turn aspired to leave the homestead for better employment or a different way of life. ${ }^{99}$ The second group of families wanted public schools to make their children better farmers so they would stay on the farm. According to the Agricultural Extension Service reports, one of the greatest threats to country life was the exodus of farming girls and boys. ${ }^{100}$ In response, this organization and others like it implemented agricultural education at schools and in the broader community. At home, these parents encouraged their children to learn about farm life, and in their spare time sent their children to agricultural clubs. ${ }^{101}$

Because mothers advocated for their own and their children's education, they made the rural school the center of the community and saw themselves as a vital part of its success. Many rural families attended gatherings at the school together, and these socials, debates, or

\footnotetext{
98 Ansel Peterson Hornor, interview by Margaret Mary Lewis, October 1, 1981, Voices of American Homemakers, Eleanor Arnold, Editor and Project Director, Paterno Library, PSU. According to Tyack and Hansot in Learning Together, rural families were more willing to support co-education because family, church, and school were mixedsex; thus "gender practices moved easily through the permeable membranes that joined the three social agencies in rural communities" (59).

${ }^{99}$ Milton Jimison Ferguson, interview transcript, p. 5-6, Marshall University Oral History of Appalachia, WVU; J. Richard Campbell, interviewed by Cynthia Legard, August 27, 1973, transcript, p. 1-3, The Appalachian Oral History Project, WVU; Hal S. Barron, Mixed Harvest: The Second Great Transformation in the Rural North (Chapel Hill: The University of North Carolina Press), 68-77.

${ }^{100}$ Report of Agricultural Extension Work of the College of Agriculture, West Virginia University, 1911-12, p. 3, in A\&M 539, "West Virginia University, Agricultural Extension Service. County Agent's Reports,” WVU.

${ }^{101}$ Ruth Hardenstine, interviewed by Kathleen McCarthy, July 21, 1975, tape 30, 3-1483 Cassette Box 195, "Pennsylvania Germans," MG-409, Pennsylvania State Archives, Harrisburg, PA.
} 
performances supplemented public education and extracurricular activities. ${ }^{102}$ Whether at formal events, like their children's Christmas pageants or at weekly meetings for debate club, mothers policed the family's efforts to learn and encouraged their participation. ${ }^{103}$ At home, they had already proven to their family members that they could take on new roles, in addition to cooking, cleaning, and child rearing. And not only did farm children take pride in their work, they also learned that girls and boys could enter into cooperative relationships and work together to operate the home and farm.

Farmwomen served as an essential component of country schools, which determined family and local life. One-room schoolhouses became the center for rural communities in the early twentieth century because countrywomen played a critical role in community identity. As more women left country life, those who stayed behind adapted the culturally embedded notions of their proper role in rural society. Many farmwomen used the education and independence that they gained in free, public schools to broaden ideas about relationships, family, and community in twentieth-century rural America.

\footnotetext{
${ }^{102}$ Ethel Tennant Arnett, "Italy School House," in Folder 3, "Little Falls" in Folder 4 and P. Wayne Harner, oral history, in Folder 6, Box 1 in A\&M 2744, "Monongalia County Schools, Reminiscences," WVU.

${ }^{103}$ Hettie Boland, interview, p. 5-7; Georgia Gray Cook, oral history; Mary K. Summers, oral history; P. Wayne Harner, oral history.
} 


\section{Chapter 5 \\ Conclusion}

Writing in the second half of the twentieth century, Lynn Hastings, a prominent school administrator for Monongalia County, West Virginia, reflected on women's education during the nineteenth century. In his history of one-room schoolhouses of Monongalia County, he recalled, "The teacher quite frequently was a man, but soon the feminine sex invaded the teaching ranks and finally surpassed it easily in number." ${ }^{.1}$ Obscured by that relatively innocuous statement was the long and circuitous path that farmgirls had followed to attain that status. Starting with a good deal of skepticism within rural communities about whether or not education was valuable for women and whether or not they could perform as well as boys, they then confronted administrators who hoped to circumscribe their options so as not to disrupt rural communities. Ultimately, rural women in West Virginia and Pennsylvania carved out their own niches within the public school system and attached their own meanings to that experience. The extent to which those experiences transformed rural communities is unclear, but for many rural-born women, the public education that they received was individually transforming.

This thesis, drawing heavily upon the memoirs, diaries, and letters of rural women, reveals that they responded in a number of ways to public education, expanded opportunities, and broadened notions of womanhood. Prior to the Civil War, few farmwomen from mountainous regions attended school, but with the rise of public education, they received advanced skills and knowledge that prepared them for a number of new roles and encouraged them to develop a sense of self. By the late nineteenth century, some countrywomen used these new skills learned in school to enhance their ability to operate farms without the help of a man or

\footnotetext{
${ }^{1}$ Lynn Hastings, ““'The One Room School in Monongalia County,” in Monongalia County School and Local History 1864-1960, Book One of Monongalia County School and Local History 1864-1960, in Box 1, A\&M 1375, "Schools, Monongalia County Board of Education, Bound Typescripts," 88.
} 
to begin thinking differently about what characteristics they sought in a mate. A small few even developed the gumption to attend medical school or enter other professions. Many used education to broaden their personal interests and activities, like volunteering or socializing, or to find an appropriate career, like teaching in a one-room schoolhouse. Yet even with these expanded possibilities, most rural women married and continued living in the same community that their families had populated for generations.

Many of these new opportunities appeared as mountain communities established public schools throughout the nineteenth century. Confronting economic and social change required that Americans have access to new skills and knowledge that was essential to a modernizing society. To educate these citizens, national leaders believed that free, public schools could provide necessary skills and serve as the sounding board for democratic ideals, such as patriotism, productivity, and morality. In the decades after the Civil War, rural, mountainous areas organized and systematized schools in reaction to a rising consumer culture, rapid industrialization, and growing urban centers. By the late nineteenth century, states had gradually enacted and enforced compulsory education, established county high schools, and developed new curricula. In turn, new educational policies changed the aim of education from forming a democratic citizenry to preparing boys and girls for practical roles after school.

The rise of free, public schools brought increased access to education, but at first, it threatened rural society. Because public schools brought urban-style education to rural communities, a number of country people resisted the change. By the late nineteenth century, however, the majority of locals came to accept and enforce public education as they increased their participation in broader markets and a burgeoning consumer culture. During this time, rural people began to view public education not as a threat but as a way to improve their lives. School 
curricula provided skills that made farming more efficient, and it also supplied rural students with the knowledge to leave the family farm for better economic opportunities. Recognizing the role that schools played in their daily lives, many mountain people by the turn of the century embraced their local one-room schoolhouses, and they became an integral component of rural society.

To operate public schools, the mostly male administrators had to balance their own assumptions about women's education with the public perception of women's role in rural society. Early leaders confronted fixed notions of women's proper role, and many only supported women's education when teachers promised to prepare girls for motherhood. The Civil War expedited the shift in attitudes as women replaced male teachers, and many administrators soon heralded women's nurturing abilities, which they believed suited them for teaching. This support for female teachers continued after the Civil War and paralleled national trends of support for female education. Administrators' debate about female teachers informed their concurrent debate about female education, which gradually broadened to include more complex notions of rural womanhood. Some male administrators voiced anxiety about this "feminization," but many gradually accepted the growing number of schoolgirls. To offset this change, some called for traditional gender norms, yet despite the backlash, broader society generally supported these expanding opportunities for women.

This thesis argues that administrators in mountain communities begrudgingly expanded the notions of countrywomen's proper role as rural society gradually changed. By publishing articles in various newspapers and education journals, school leaders attempted to put boundaries on rural women's advancement as they reacted to the public's morphing perception of women's duties. From the nineteenth to the twentieth century, they broadened their ideas about women's 
education, which shifted from domestic training to practical instruction that provided the same curriculum and skills that it offered boys. Few women wrote in these journals, but as it becomes clear in this chapter, women became their own advocates as administrators broadened their ideas about women's proper role in rural society throughout the nineteenth century.

With these new experiences bought about by public education, rural women became their own self-advocates and were able to use their education in a variety of ways. At school, young girls escaped farm life and often found fun and friendships. At the same time, the public schools prepared girls for a number of possibilities. Their studies trained them for the traditional station of motherhood, and it taught them additional skills that could be used when they took on masculine roles. A few women after graduation decided to pursue a career as well as to provide for themselves. Others, such as those women who taught for a few years and then married, developed a certain level of autonomy. Nevertheless, most rural women married directly after school, and some brought these broadened expectations into the home.

This thesis argues that farmwomen in the late nineteenth century used the skills gained at school to place themselves at the center of rural society. Because most rural women married and remained on the farm, many used learning to develop their own interests and maintain the family's well being. A number of farmwomen sought ways to fulfill their personal goals, such as by reading during their spare time or organizing women's groups. Many also advocated for their own education by calling for women's agricultural clubs and subscribing to farming magazines. At the same time, they enforced learning in their own homes and prompted their husbands to do the same. By the twentieth century, many farmwomen sent their children to school regularly and encouraged them to join youth agricultural clubs. 
By advocating for education, many farmwomen in the twentieth century believed that the country school was the center of the community, and they saw themselves as an essential part of its success. Not only did most farmwomen send their children to school regularly, but they also used the schoolhouse as a site for community instruction. Often upon the mother's insistence, many rural families went to the nearby one-room schoolhouse for various socials, literary debates, and performances. There, farmwomen advocated for their own and their family's education as well as stimulated social interaction - and in the end they helped to shape their community's identity. 


\section{Bibliography}

\section{Primary Sources}

\section{Oral Histories}

The Appalachian Oral History Project of Alice Lloyd College, Appalachian State University, Emory and Henry College, and Lees Junior College, West Virginia and Regional History Collection, West Virginia University, Morgantown, West Virginia

Bausell, Elwood

Campbell, J. Richard

Ferguson, Milton Jimison

Local Oral History Project, Paterno Library, Pennsylvania State University, State College, Pennsylvania

Bottorf, Helen

Clouser, Kathrine Houser

Hussey, Maude Krumrine

Marshall University Oral History of Appalachia, West Virginia and Regional History Collection, West Virginia University, Morgantown, West Virginia

Adams, Donivon Edwin

Adkins, Lillie

Asbury, Bertha May

Atkinson, F. C.

Ball, Fay

Blatt, Pauline McGraw

Boland, Hettie

Currence, Nancy McNeel

Ellis, Grace Sunbeam

Filson, Bertha

Jarrell, America Miller

Kessell, Mr. and Mrs J. C.

Langdon, Maude

Nunn, Gladyce K.

Rowe, Martha G.

Summers, James F. and Ivy B.

Vance, Marion and Walter

Pennsylvania German Oral History, MG-409, Pennsylvania State Archives, Harrisburg, Pennsylvania

Hardenstine, Ruth

Voices of American Homemakers, Eleanor Arnold, Editor and Project Director, Paterno Library, Pennsylvania State University, State College, Pennsylvania

Hornor, Ansel Peterson

Humphreys, Gertrude 


\section{Manuscripts}

Chestnut Ridge Historical Society, Jones Mills, Pennsylvania

Ida Blackburn Collection

Citizens Library, Washington, Pennsylvania

Washington Female Seminary Collection

Huntingdon County Historical Society Archives, Huntingdon, Pennsylvania

School Records, Boxes 1-3

Greensburg Historical Society, Greensburg, Pennsylvania

Null Collection

Fayette County Historical Society, Uniontown, Pennsylvania

Census for Fayette County

Ella Peach Folder

West Virginia and Regional History Collection, West Virginia University, Morgantown, West Virginia

A\&M 462, "Monongalia County Schools Catalogue."

A\&M 539, "WVU, Agricultural Extension Service. County Agent's Reports."

A\&M 831, "Waitman Barbe Collection."

A\&M 842, "West Virginia School and Agricultural Statistics."

A\&M 1375, "Schools, Monongalia County Board of Education, Bound Typescripts."

A\&M 1845, "Bessie Jane Reed Collection."

A\&M 1984, "Schools, Morgantown."

A\&M 2135, "Wilson-Lewis Family Papers."

A\&M 2607, "Lucy Clark Wise Papers."

A\&M 2621, "Storer College."

A\&M 2744, "Monongalia County Schools. Reminiscences."

A\&M 2864, "Lucy Bayard Keyes Papers."

A\&M 2876, "Putney-Reed Family Papers."

A\&M 3050, "West Virginia Country Life Movement, 1919-27."

A\&M 3187, "Robert E. Lee Keadle, Monroe County Diary."

\section{Newspapers and Serials}

Chambersburg Valley Spirit

The Columbia Democrat

The Daily Athenaeum

The Daily Courier

Godey's Lady's Book

Harper's Bazaar

Jeffersonian Republican

Juniata Sentinel and Republican

The Ladies' Garland

Lewisburg Chronicle 
The Mountain Sentinel

The Pennsylvania Farm Journal

The Pennsylvania School Journal

Scribner's Monthly

The Somerset Herald

The Star

Sunbury American and Shamokin Journal

Valley Farmer

The West Virginia School Journal

\section{Public Documents}

Ambler, Charles H., Atwood, Frances H., and Mathews, William B. Editors. Debates and Proceedings of the First Constitutional Convention of West Virginia, (1861-1863). Huntington: Gentry Brothers, 1942.

Ancestry Library Edition

West Virginia Deaths Index

West Virginia Marriages Index

1850 Census

1880 Census

1910 Census

1920 Census

1930 Census

1940 Census

Barbe, Waitman. In the Virginias, Stories and Sketches. Akron, Ohio: The Werner Company, 1896.

Beecher, Catharine E. Suggestions Respecting Improvements in Education, Presented to the Trustees of the Hartford Female Seminary, and Published at their Request. Hartford: Hudson and Skinner, 1829.

. A Treatise on Domestic Economy For the Use of Young Ladies At Home and At School. Revised Edition. Boston: Thomas H. Webb, 1843.

Clarke, Edward H. Sex in Education; or A Fair Chance for Girls. Boston: Rand, Avery, \& Company, 1873.

Coburn, Charles R. Report of the Superintendent of Common Schools of Pennsylvania, For the Year Ending June 4, 1863. Harrisburg: Singerly \& Myers, 1864.

Cutright, W.B. The History of Upshur County, West Virginia, From its Earliest Exploration and Settlement to the Present Time. Buckhannon, West Virginia, 1907. 
Eagle, Mary Kavanaugh Oldham. Editor. The Congress of Women Held in the Woman's Building, World's Columbian Exposition, Chicago, U.S.A. Chicago: W.B. Conkey Company, 1894.

Hickok, Henry C. Report of the Superintendent of Common Schools of Pennsylvania, For the Year Ending June 2, 1857. Harrisburg: A. Boyd Hamilton, 1858.

Howe, Julia Ward. Sex and Education: A Reply to Dr. E.H. Clarke's "Sex in Education." Boston: Roberts Brothers, 1874.

Hutter, E. W. Female Education: Its Importance, The Helps and the Hindrances: Address Delivered Before the Faculty and Students of the Susquehanna Female College, at Selinsgrove, PA. Baltimore: T. Newton Kurtz, 1859.

Mann, Horace. A Few Thoughts on the Powers and Duties of Woman, Two Lectures. Syracuse: Hall, Mills, and Company, 1853.

Pennsylvania. Agriculture of Pennsylvania Containing Reports of the State Board of Agriculture: The State Agricultural Society, The State Dairy-Men's Association, The State Horticultural Association, and the State College, For 1887. Harrisburg: Edwin K. Meyers, 1888.

. History of Tioga County, Pennsylvania. Harrisburg: R.C. Brown, 1897.

. Reports of the State Board of Agriculture. Harrisburg: Edwin K. Meyers, State Printer, 1890.

Russell, A. L. Seventeenth Annual Report of the Superintendent of Common Schools of Pennsylvania, For the School Year Ending June 1, 1850. Harrisburg, 1851.

Schaeffer, Nathan C. Report of the Superintendent of Public Instruction of the Commonwealth of Pennsylvania, For the Year Ending July 6, 1914. Harrisburg; William Stanley Ray, 1914.

Shawkey, M. P. Biennial Report of the State Superintendent of Free Schools of West Virginia for the Two Years Ending June 30, 1914. Charleston: Department of Free Schools, 1914.

. Biennial Report of the State Superintendent of Free Schools of West Virginia for the Two Years Ending June 30, 1916. Charleston: Tribune Printing Company, 1916.

Waller, D. J. Report of the Superintendent of Public Instruction of the Commonwealth of Pennsylvania For the Year Ending June 2, 1890. Harrisburg: Edwin K. Meyers, 1890.

West Virginia, History of the Great Kanawha Valley, With Family History and Biographical Sketches. $2^{\text {nd }}$ Volume. Madison: Brant, Fuller \& Company, 1891. 
Wickersham, James P. Report of the Superintendent of Common Schools of the Commonwealth of Pennsylvania, For the Year Ending June 4, 1866. Harrisburg: Singerly \& Myers, 1867. . Report of the Superintendent of Common Schools of the Commonwealth of Pennsylvania, For the Year Ending June 3, 1867. Harrisburg: Singerly \& Myers, 1868.

. Report of the Superintendent of Common Schools of the Commonwealth of

Pennsylvania, For the Year Ending June 3, 1872. Harrisburg: B. Singerly, 1872.

White, W. R. Second Annual Report of the State Superintendent of Free Schools, of the State of West Virginia. Wheeling: John Frew, 1866.

. Third Annual Report of the State Superintendent of Free Schools of the State of West Virginia. Wheeling: John Frew, 1867.

\section{Secondary Sources}

\section{Books}

Ambler, Charles H. A History of Education in West Virginia From Early Colonial Times to 1949. Huntington: Standard Printing \& Publishing Company, 1951.

Ambler, Charles H. and Summers. Festus P. West Virginia: The Mountain State. Englewood Cliffs: Prentice-Hall, 1940.

Bailyn, Bernard. Education in the Forming of American Society: Needs and Opportunity for Study. New York: Vintage Books, 1960.

Barron, Hal S. Mixed Harvest: The Second Great Transformation in the Rural North, 1870-1930. Chapel Hill: The University of North Carolina Press, 1997.

Bederman, Gail. Manliness and Civilization: A Cultural History of Gender and Race in the United States, 1880-1917. Chicago: The University of Chicago Press, 1995.

Bowers, William L. The Country Life Movement in America, 1900-1920. Port Washington: Kennikat Press, 1974.

Casteel, Hazel H., Nesius, Ernest J., and Fasching, Joseph L. One-Room Schools in Monongalia County, West Virginia. Morgantown: Monongalia Historical Society, 1997.

Censer, Jane Turner. The Reconstruction of White Southern Womanhood, 1865-1895. Baton Rouge: Louisiana State University Press, 2003.

Cremin, Lawrence. The Transformation of the School: Progressivism in American Education, 1876-1957. New York: Knopf, 1961. 
Dunaway, Wilma. Women, Work, and Family in the Antebellum Mountain South. New York: Cambridge University Press, 2008.

Farnham, Christie Anne. The Education of the Southern Belle: Higher Education and Student Socialization in the Antebellum South. New York: New York University Press, 1994.

Fausto-Sterling, Anne. Myths of Gender: Biological Theories About Women and Men. New York: Basic Books, 1985.

Fletcher, Stevenson W. Pennsylvania Agriculture and Country Life, 1840-1940. Harrisburg: Pennsylvania Historical and Museum Commission, 1955.

Gould, Stephen Jay. The Mismeasure of Man. New York: W.W. Norton \& Co., 1981.

Herbst, Jurgen. And Sadly Teach: Teacher Education and Professionalization in American Culture. Madison: University of Wisconsin Press, 1989.

Horowitz, Helen Lefkowitz. Alma Mater: Design and Experience in the Women's Colleges from Their Nineteenth Century Beginnings to the 1930s. New York: Knopf, 1984.

Jensen, Joan M. Loosening the Bonds: Mid-Atlantic Farm Women, 1750-1850. New Haven: Yale University Press, 1986.

Jones, Lu Ann. Mama Learned Us to Work: Farm Women in the New South. Chapel Hill: The University of North Carolina Press, 2002.

Kaestle, Carl F. Pillars of the Republic: Common Schools and American Society, 1780-1960. New York: Hill and Wang, 1983.

Kelly, Mary. Learning to Stand and Speak: Women, Education, and Public Life in America's Republic. Chapel Hill: The University of North Carolina Press, 2006.

Link, William A. A Hard Country and a Lonely Place: Schooling, Society, and Reform in Rural Virginia, 1870-1920. Chapel Hill: The University of North Carolina Press, 1986.

McMurry, Sally. Families and Farmhouses in Nineteenth-Century America: Vernacular Design and Social Change. New York: Oxford University Press, 1988.

Nash, Margaret A. Women's Education in the United States, 1780-1840. New York: Palgrave Macmillan, 2005.

Pennsylvania. Agricultural Resources of Pennsylvania, c.1700-1960: Southwest Pennsylvania Diversified and Sheep Raising, c.1840-1960. Harrisburg: Pennsylvania Historical Museum Commission, 2009. 
Perlmann, Joel and Margo, Robert A. Women's Work?: American Schoolteachers, 1650-1920. Chicago: University of Chicago Press, 2001.

Osterud, Nancy Grey. Bonds of Community: The Lives of Farm Women in Nineteenth-Century New York. Ithaca: Cornell University Press, 1991.

. Putting the Barn Before the House: Women and the Family Farming in Early TwentiethCentury New York (Ithaca: Cornell University Press, 2012).

Rasmussen, Wayne D. Taking the University to the People: Seventy-Five Years of Cooperative Extension. Ames: Iowa State University Press, 1988.

Rury, John L. Education and Women's Work: Female Schooling and the Division of Labor in Urban America, 1870-1930. Albany: State University of New York Press, 1991.

Sklar, Kathryn Kish. Catharine Beecher: A Study in American Domesticity. New Haven: Yale University Press, 1973.

Solomon, Barbara Miller. In the Company of Educated Women: A History of Women and Higher Education in America. New Haven: Yale University Press, 1985.

Stanley, Amy Dru. From Bondage to Contract: Wage Labor, and the Market in the Age of Slave Emancipation. New York: Cambridge University Press, 1998.

State Superintendent of Schools. The History of Education in West Virginia. Revised Edition. Charleston: Tribune Printing Company, 1907.

Stoddart, Jess. Challenge and Change in Appalachia: The Story of Hindman Settlement School. Lexington: The University Press of Kentucky, 2002.

Theobald, Paul. Call School: Rural Education in the Midwest to 1918. Carbondale: Southern Illinois University, 1995.

Trefousse, Hans L. Thaddeus Stevens: Nineteenth-Century Egalitarian. Chapel Hill: The University of North Carolina Press, 1997.

Tyack, David. The One Best System: A History of American Urban Education. Cambridge: Harvard University Press, 1974.

Tyack, David and Hansot, Elisabeth. Learning Together: A History of Coeducation in American Schools. New Haven: Yale University Press, 1990.

Walker, Melissa. All We Knew Was to Farm: Rural Women in the Upcountry South, 1919-1914. Baltimore: Johns Hopkins University Press, 2000. 
Weiler, Kathleen. Country Schoolwomen: Teaching in Rural California, 1850-1950. Stanford: Standford University Press, 1998.

Willey, William P. An Inside View of the Formation of the State of West Virginia. Wheeling: The News Publishing Company, 1901.

Woodley, Thomas Frederick. Great Leveler: The Life of Thaddeus Stevens. New York: Stackpole Sons, 1937.

Whites, LeeAnn. The Civil War as a Crisis in Gender: Augusta, Georgia, 1860-1890. Athens: University of Georgia Press, 1995.

. Gender Matters: Civil War, Reconstruction, and the Making of the New South. New York: Palgrave Macmillan, 2005.

Articles

Beadie, Nancy. "Academy Students in Mid-Nineteenth Century: Social Geography, Demography, and the Culture of Academy Attendance." History of Education Society 41, no. 2 (Summer 2001): 251-262.

Blazier, George J. "The Pioneer Battelles and their Contributions to the Building of Ohio and West Virginia.” West Virginia History 15, no. 3 (April 1954): 258-268.

Eagan, Shirley C. “'Women's Work, Never Done': West Virginia Farm Women, 1880s-1920s.” West Virginia History 49 (1990): 21-36.

Hagler, D. Harland. "The Ideal Woman in the Antebellum South: Lady or Farmwife?" The Journal of Southern History 46, no. 3 (August 1980): 405-418.

Kerber, Linda. "The Republican Mother: Women and the Enlightenment — an American Perspective." American Quarterly 28, no. 2 (Summer 1976): 187-205.

Lewis, Jan. "The Republican Wife: Virtue and Seduction in the Early Republic." William and Mary Quarterly 44, no. 4 (October 1987): 689-721.

McCleary, Ann. "Work in Progress: Domesticity and the Farm Woman: A Case Study of Women in Augusta County, Virginia, 1850-1940." Perspectives in Vernacular Architecture 1 (1982): 25-30.

McMahon, Lucia. "Of the Utmost Importance to Our Country": Women, Education, and Society, 1780-1820." Journal of the Early Republic 29, no. 3 (Fall 2009): 475-506.

Nicholson, Linda. “Interpreting Gender.” Signs 20, no. 1 (Autumn, 1994): 79-105.

O’Brien, Robert J. "Persecution and Acceptance: The Strange History of Discrimination Against Married Women Teachers in West Virginia.” West Virginia History 56 (1997): 56-75. 
Perry, Allyson. "The Gendered Profession: West Virginia Administrators React to Women in Education, 1863-1917." Graduate History Review 4, no. 1 (Fall 2012): 29-42.

Stevens, Edward, Katz, Michael, and Vinovskis, Maris A. "Forum: The Origins of Public High Schools.” History of Education Quarterly 27 (Summer 1986): 241-258.

Strober, Myra H. and Lanford, Audri Gordon. "The Feminization of Public School Teaching: Cross-Sectional Analysis, 1850-1880.” Signs 11, no. 2 (Winter, 1986): 212-235.

Tolley, Kim. "Science for Ladies, Classics for Gentlemen: A Comparative Analysis of Scientific Subjects in the Curricula of Boys' and Girls' Secondary Schools in the United States, 1794-1850." History of Education Quarterly 36, no. 2 (Summer 1996): 129-153.

Vossler, Ruth Babb. "Women and Education in West Virginia, 1810-1909." West Virginia History 36 (July 1975): 271-290.

Waugh, Lillian J. and Stizel, Judith G. "“Anything But Cordial': Coeducation and West Virginia University’s Early Women.” West Virginia History 49 (1990): 69-80.

Welter, Barbara. "The Cult of True Womanhood: 1820-1860.” American Quarterly 18, no. 2 (Summer 1966): 151-174.

\section{Theses}

Fisher, Ruth Coe. "A History of Women in Education in West Virginia." Master's Thesis, Marshall College, 1947.

Fredette, Allison. "The View from the Border: A Study of Gender and Women's Rights in West Virginia During the Age of Emancipation.” Master's Thesis, West Virginia University, 2008. 